Pacific Northwest National Laboratory

Operated by Battelle for the

U.S. Department of Energy

\section{RCRA Assessment Plan for Single-Shell Tank Waste Management Area A-AX at the Hanford Site}

S M. Narbutovskih

C. J. Chou

March 2006

Prepared for the U.S. Department of Energy under Contract DE-AC05-76RL01830 


\title{
DISCLAIMER
}

This report was prepared as an account of work sponsored by an agency of the United States Government. Reference herein to any specific commercial product, process, or service by trade name, trademark, manufacturer, or otherwise does not necessarily constitute or imply its endorsement, recommendation, or favoring by the United States Government or any agency thereof, or Battelle Memorial Institute.

\author{
PACIFIC NORTHWEST NATIONAL LABORATORY \\ operated by \\ BATTELLE \\ for the \\ UNITED STATES DEPARTMENT OF ENERGY \\ under Contract DE-AC05-76RL01830
}

\author{
Printed in the United States of America \\ Available to DOE and DOE contractors from the \\ Office of Scientific and Technical Information, P.O. Box 62, Oak Ridge, TN 37831; \\ prices available from (615) 576-8401.
}

Available to the public from the National Technical Information Service,
U.S. Department of Commerce, 5285 Port Royal Rd., Springfield, VA 22161

(4) This document was printed on recycled paper. 


\title{
RCRA Assessment Plan for Single-Shell Tank Waste Management Area A-AX at the Hanford Site
}

\author{
S. M. Narbutovskih \\ C. J. Chou
}

March 2006

Prepared for

the U.S. Department of Energy

under Contract DE-AC05-76RL01830

Pacific Northwest National Laboratory

Richland, Washington 99352 


\section{Summary}

This document was prepared as a groundwater quality assessment plan for the single-shell tank systems in Waste Management Area A-AX at the Hanford Site. Groundwater monitoring is conducted at this facility in accordance with Title 40, Code of Federal Regulation (CFR) Part 265, Subpart F and by reference of Washington Administrative Code [WAC] 173-303-400(3). The groundwater monitoring program has been changed from detection-level indicator evaluation to a groundwater-quality assessment program because of elevated specific conductance. Quadruplicate measurements of specific conductance collected June 2005 from downgradient well 299-E25-93 averaged $536 \mu \mathrm{S} / \mathrm{cm}$, which exceeded the critical mean value of $522 \mu \mathrm{S} / \mathrm{cm}$. Required verification sampling conducted July 2005 confirmed the exceedance was statistically significant.

Groundwater monitoring objectives of RCRA, CERCLA, and the AEA often differ slightly, and the contaminants monitored are not always the same. For RCRA regulated units, monitoring focuses on nonradioactive dangerous waste constituents. Radionuclides (source, special nuclear, and by-product materials) may be monitored in some RCRA unit wells to support objectives of monitoring under the AEA and/or CERLCA. Please note that pursuant to RCRA, the source, special nuclear and by-product material component of radioactive mixed wastes, are not regulated under RCRA and are regulated by DOE acting pursuant to its AEA authority. Therefore, while this report may be used to satisfy RCRA reporting requirements, the inclusion of information on radionuclides in such a context is for information only and, may not be used to create conditions or other restrictions set forth in any RCRA permit.

A first determination, as allowed under 40 CFR 265.93(d)(5), provides the owner/operator of a facility an opportunity to determine if dangerous waste from the regulated unit have entered the groundwater. This plan, developed using the data quality objectives process, complies with this initial investigation requirement. Accordingly, the primary purpose of the present plan is to guide investigations for a first determination. The results of these studies will assist in deciding if operations associated with the waste management area have compromised groundwater quality with dangerous waste. Planned activities and investigations were addressed in the descriptive narrative of this plan, which includes a tentative schedule for this first determination. 


\section{Contents}

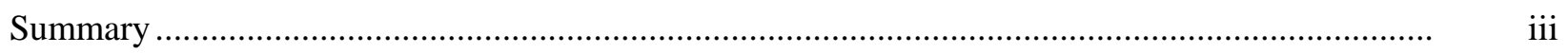

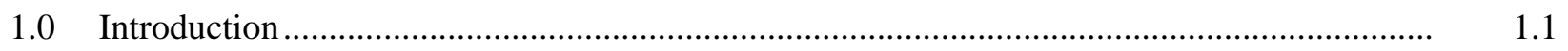

1.1 Statement of the Assessment Condition ................................................................... 1.1

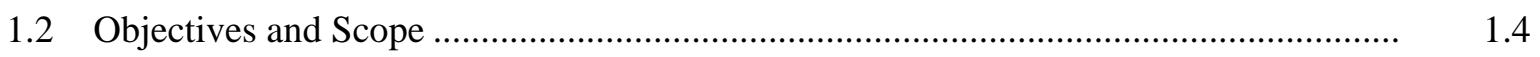

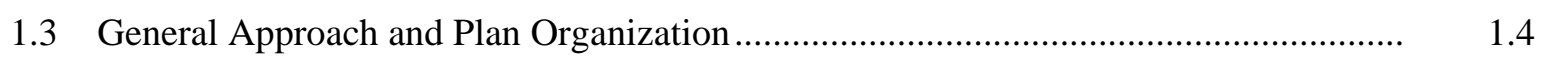

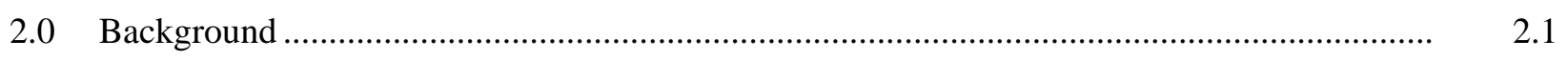

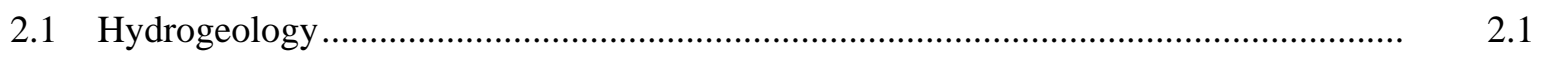

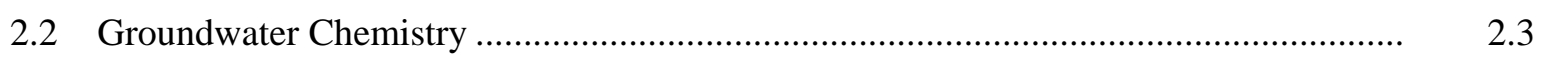

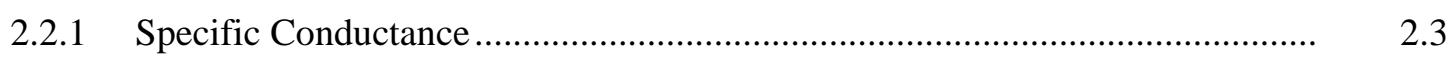

2.2.2 Co-Varying Constituents .......................................................................... 2.3

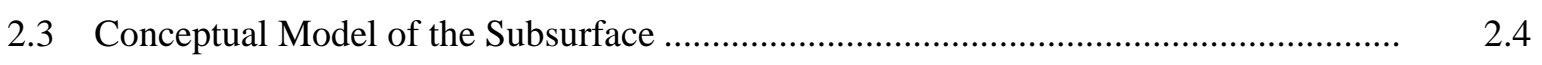

2.3.1 Contaminant Sources................................................................................. 2.6

2.3.2 Driving Forces................................................................................... 2.9

2.3.3 Migration Pathways............................................................................. $\quad 2.10$

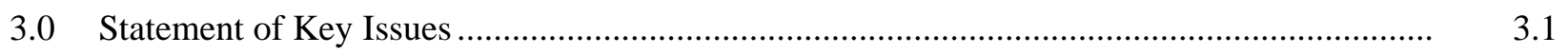

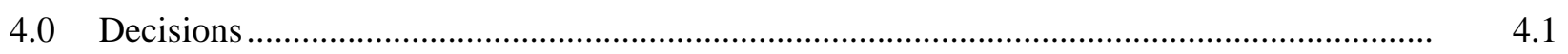

5.0 Information Needs and Decision Rules...................................................................

5.1 Characterization and Distribution of Contaminants .............................................. 5.1

5.1.1 Tank-Related Dangerous Waste Constituents ................................................ 5.1

5.1.2 Areal Extent of Groundwater Contamination.................................................. 5.2

5.2 Monitoring Well Network ...................................................................................... 5.3

5.3 Indication of Dangerous Waste or Dangerous Waste Constituents.............................. 5.4

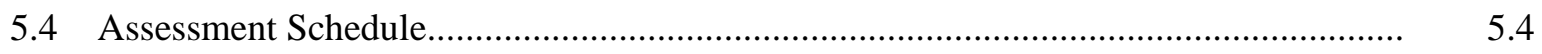

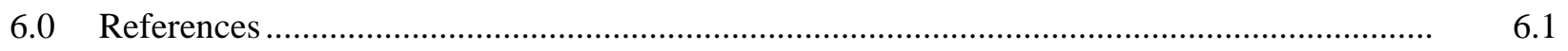

Appendix A - Sampling and Analysis Plan........................................................................... A.1

Appendix B - As-Built Diagrams of Groundwater Monitoring Wells at Waste Management

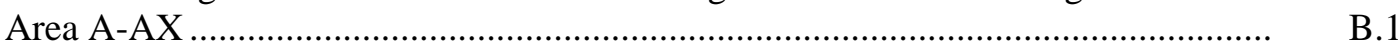




\section{Figures}

1.1 Location of the 200 East Area Within the DOE Hanford Site in Washington State................

1.2 Location Map of Groundwater Monitoring Wells Around Waste Management

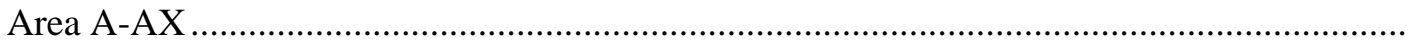

2.1 Hydrographs of Water Elevations at WMA A-AX ................................................................. 2.2

2.2 Time Series Trends of Specific Conductance in the Groundwater at WMA A-AX ............... 2.4

2.3 Time Series Trends of Sulfate and Nitrate in the Groundwater at WMA A-AX ....................

2.4 Time Series Trends of Technetium-99 in the Groundwater at WMA A-AX......................... 2.6

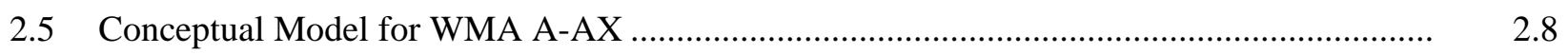

4.1 Flowchart Illustrating the DQO Decisions for the WMA A-AX Assessment Program........... 4.2 


\subsection{Introduction}

Since 1944, the single-shell tanks at Hanford have contained hazardous chemical waste generated from plutonium production and separation activities. The 149 single-shell tanks are hazardous waste management units regulated under the Resource Conservation and Recovery Act (RCRA) and Washington's Hazardous Waste Management Act (HWMA, RCW 70.105) and it's implementing requirements (Washington's Dangerous Waste Regulations, WAC 173-303).

Two single-shell tank farms, 241-A and 241-AX, constitute the Waste Management Area (WMA) A-AX defined for use in developing and operating the groundwater monitoring network. This WMA is located in the 200 East Area of the DOE Hanford Site (Figure 1.1). The facilities in this WMA are included in the RCRA Dangerous Waste Permit Application, PART A (interim status) submitted in accordance with 40 Code of Federal Regulations (CFR) 265.93. A map of the WMA is shown in Figure 1.2.

Groundwater monitoring objectives of RCRA, CERCLA, and the AEA often differ slightly, and the contaminants monitored are not always the same. For RCRA regulated units, monitoring focuses on nonradioactive dangerous waste constituents. Radionuclides (source, special nuclear and by-product materials) may be monitored in some RCRA unit wells to support objectives of monitoring under the AEA and/or radioactive mixed wastes, are not regulated under RCRA and are regulated by DOE acting pursuant to its AEA authority. Therefore, while this report may be used to satisfy RCRA reporting requirements, the inclusion of information on radionuclides in such a context is for information only and, may not be used to create conditions or other restrictions set forth in any RCRA permit.

\subsection{Statement of the Assessment Condition}

Until recently, groundwater beneath this WMA was monitored under an interim status detection-level indicator evaluation program in accordance with the RCRA of 1976, as described in 40 CFR 265, Subpart F, by reference of Washington State Administrative Code (WAC) 173-303-400 (3). The interim status monitoring plans in the past were designed to meet interim status requirements for WMA A-AX (PNNL-13023; WHC-SD-EN-AP-012; WHC-SD-EN-AP-012).

Results from the interim status RCRA semi-annual sampling in June 2005 at one downgradient well, 299-E25-93, showed an average concentration of $536 \mu \mathrm{S} / \mathrm{cm}$ for the indicator parameter, specific conductance. This value exceeded the critical mean for this parameter of $522 \mu \mathrm{S} / \mathrm{cm}$. Results from verification sampling confirmed that the specific conductance is above the critical mean with a value of $538 \mu \mathrm{S} / \mathrm{cm}$. Thus, the monitoring at WMA A-AX has been elevated into RCRA assessment.

A first determination, as allowed under 40 CFR 265.93(d)(5), provides the owner/operator of a facility the opportunity to determine whether dangerous waste or dangerous waste constituents from the regulated unit have compromised groundwater quality. This plan, developed using the data quality objectives (DQO) process, is intended to comply with this initial investigation requirement. Accordingly, the primary purpose of the present plan is to determine if operations associated with the WMA have compromised groundwater quality with dangerous waste or waste constituents (WAC 173-303-9905). 


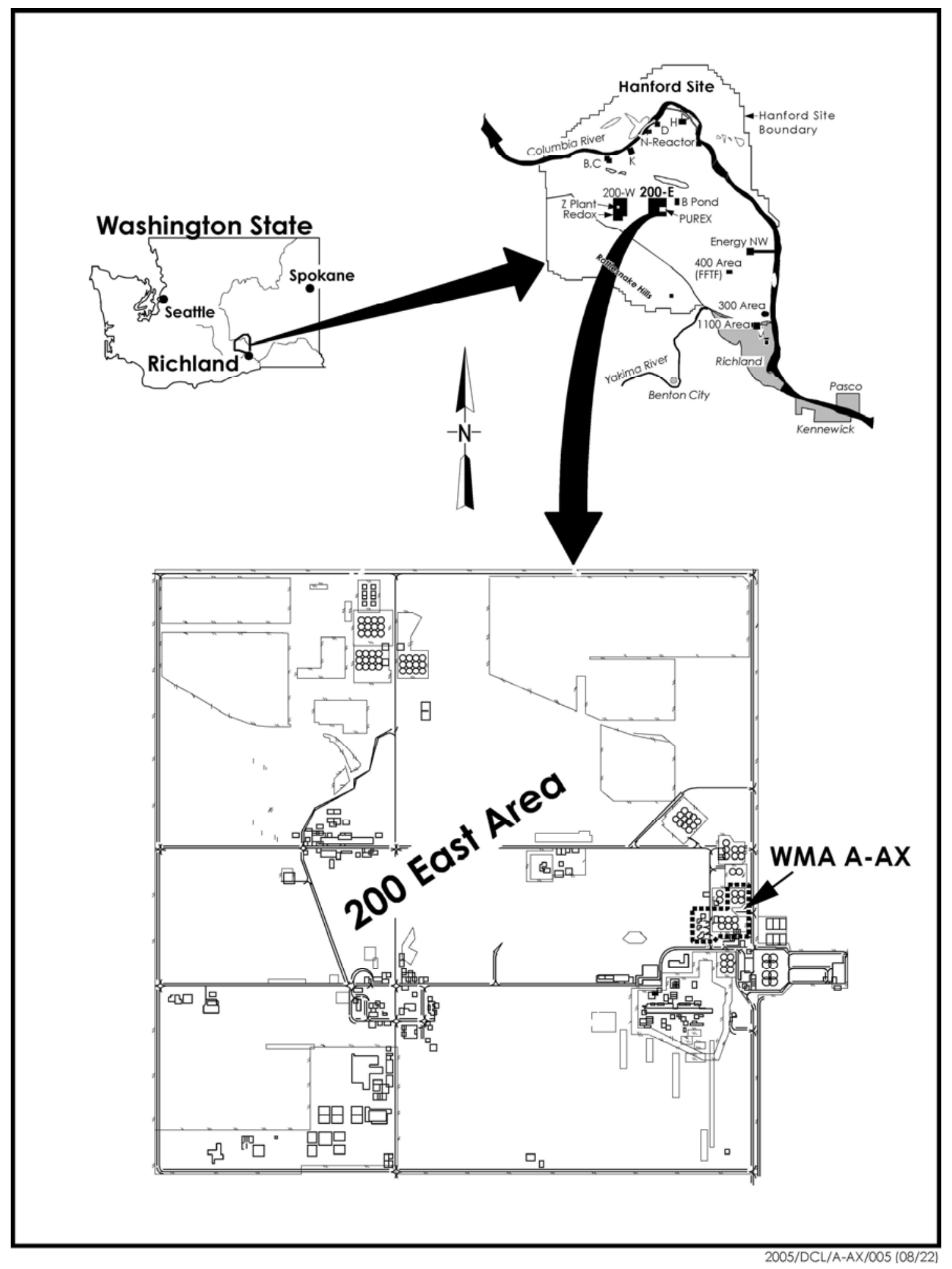

Figure 1.1. Location of the 200 East Area Within the DOE Hanford Site in Washington State 


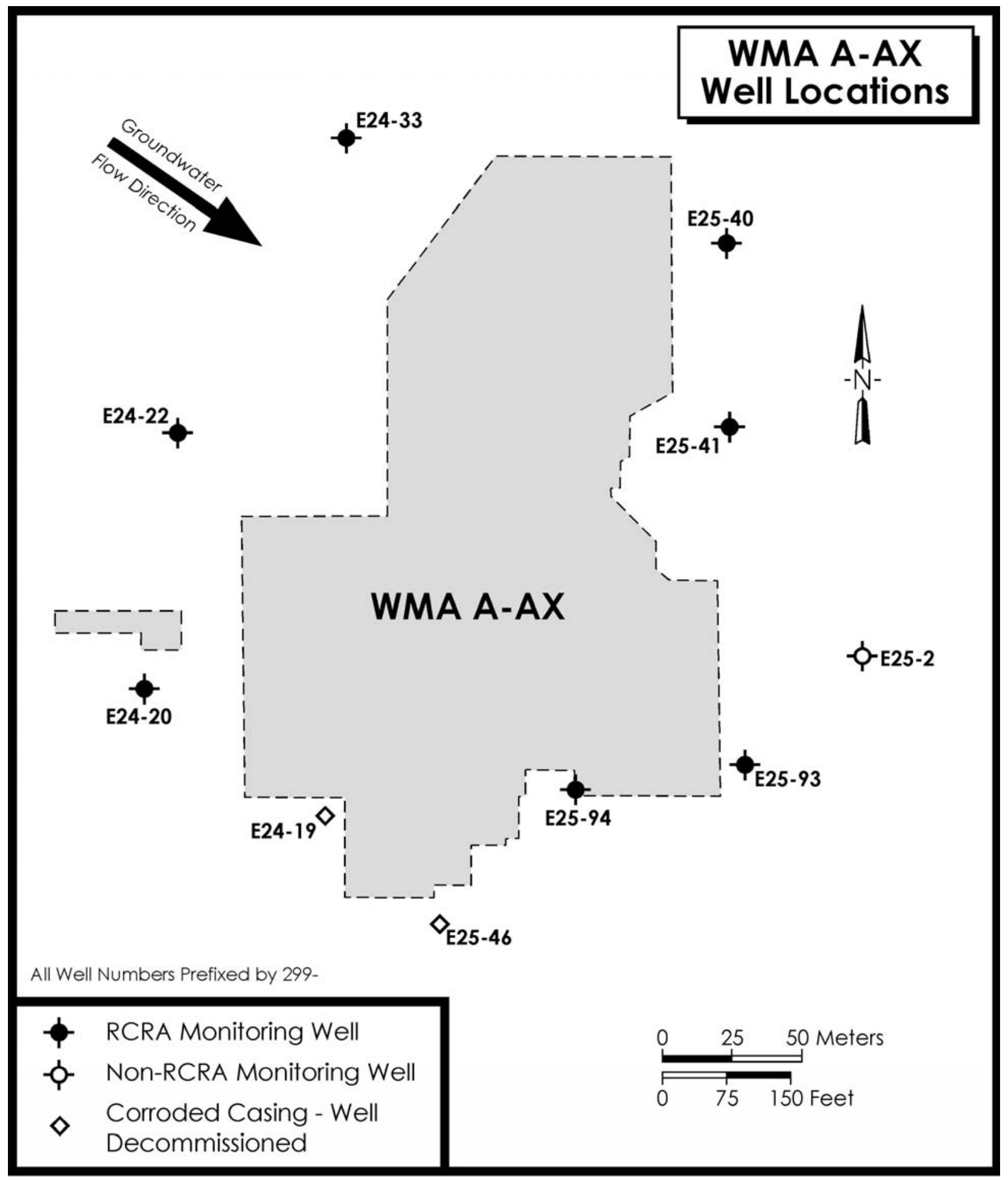

2005/DCL/A-AX/010 (10/14)

Figure 1.2. Location Map of Groundwater Monitoring Wells Around Waste Management Area A-AX 


\subsection{Objectives and Scope}

In accordance with the primary purpose of this first determination investigation, planned groundwater monitoring activities are described in the following paragraphs. A tentative schedule for completion of this first determination is provided. However, a final schedule may be influenced by changes in the status of the groundwater chemistry over time.

The specific objectives of this groundwater quality assessment plan are:

- Determine the appropriate tank waste constituents to monitor in the groundwater, including the sampling frequency.

- Fulfill requirements specified in 40 CFR 265.93(d)(5). Specifically to make a first determination, investigate the role of tank farm operations on the local groundwater quality as required under 40 CFR 265.93(d)(6) and (7).

- Investigate local surrounding sources for possible groundwater contamination.

Based on the results of the first determination, if it is found that no dangerous waste or dangerous waste constituents from the WMA A-AX have entered the groundwater, the site will be reinstated to an indicator evaluation program [40 CFR 265.93(d)(6)]. If, however, the first determination confirms dangerous waste or dangerous waste constituents from the facility have compromised the groundwater quality, further assessment activities will be initiated under a separate plan to determine the rate, extent, and concentration of the migrating contaminants [40 CFR 265.93(d)(7)].

This plan defines the monitoring network, constituents, and schedule based on the outcome of applying the DQO process (EPA 2000). It should be noted that this plan does not cover a detailed facility description and related information. This detailed information can be found in the interim status groundwater monitoring plan, RCRA Groundwater Monitoring Plan for Single-Shell Tank Waste Management Area A-AX at the Hanford Site (PNNL-13023). The document includes an extensive description of facility history, waste characteristics for WMA A-AX, local geologic stratigraphy, a detailed conceptual model of the subsurface, information on monitoring well construction and individual tank waste inventory. Further information on the subsurface can be found in RPP-14430, PNNL-14538, and DOE/GJO-HAN-12.

\subsection{General Approach and Plan Organization}

The plan is based on a modification of the seven data quality objectives steps, as described in Guidance for the Data Quality Objectives Process (EPA/600/R-96/055 (QA/G-4), EPA 2000, as revised), leading to a sampling and analysis plan that guides the fieldwork for various tasks. The process was originally designed by the U.S. Environmental Protection Agency (EPA) to expedite cleanup activities at superfund sites. Thus not all of the steps apply to a groundwater quality assessment. However, the DQO process was followed to the extent possible.

Applicable DQO steps are used as appropriate. The important or essential aspects of the DQO process are that key decisions are identified in the form of questions or statements and that the acquired data are appropriate to answer these questions or to make the necessary decisions. 
The DQO steps form the basis and organization of this plan. A brief description of the WMA along with existing site hydrogeologic conditions, current groundwater chemistry and a conceptual model based on vadose zone and groundwater results are provided in Section 2.0 as background for the subsequent steps in the DQO process. The key issues, specific to WMA A-AX are presented in Section 3.0 while DQO decision rules for a first determination investigation are formulated in Section 4.0.

Information needs and decision rules are presented in Section 5.0, along with a tentative assessment schedule. The final product of the DQO process is a sampling and analysis plan describing data collection that meets the quantitative and qualitative needs of the investigation. The sampling and analysis plan is presented in Appendix A. Well information of the RCRA and non-RCRA monitoring wells that will be used in the investigative activities are included in Appendix B. 


\subsection{Background}

Since 1944, dangerous waste has been generated at the DOE Hanford Site during plutonium production for national defense activities. Mixed waste left from the processing of irradiated fuel rods was stored in 149 underground single-shell tanks since that time. The WMA A-AX consists of six single-shell tanks in the 241-A Tank Farm, each with a capacity of 1 million gallons and four single-shell tanks in the 241-AX Tank Farm, each with a capacity of 1 million gallons. Also included are ancillary equipment consisting of seven diversion boxes, associated piping valve pits, pumps, and the 244-AR waste transfer vault.

In November 1980, the single-shell tanks were removed from active service and replaced by doubleshell tanks for the receipt of new waste and for transfer of waste from the single-shell tanks. Liquid has been pumped from various single-shell tanks at the DOE Hanford Site to the double-shell tanks for longterm storage (HNF-EP-0182-131). In May 1987, DOE issued a final rule (10 CFR 962) stating that the hazardous waste components of the mixed waste are subject to RCRA regulations. In November 1987, EPA authorized the Washington State Department of Ecology (Ecology) to regulate these hazardous waste components within the state of Washington (51 FR 24504).

\subsection{Hydrogeology}

This section provides information on the unconfined aquifer in the immediate region of WMA A-AX. Aquifer properties were determined from the stratigraphic interpretations, current water level, in situ measurements and aquifer tests (PNNL-13116; WMP-18472; PNNL-14538; PNNL-13023).

Based on results from recent drilling, the sand-dominated facies of the Hanford formation extends from about 3.35 to 81 meters (11 to 266 feet) below ground surface (bgs) with some coarse to fine sand interbeds. At 81 meters (266 feet) bgs, the gravel-dominated Hanford facies is encountered. The uppermost unconfined aquifer, from about 85 to 96.6 meters (280 to 317 feet) bgs, is composed primarily of the gravel-dominated facies of the permeable lower Hanford formation (WMP-18472), although this unit is described at times as reworked Ringold Formation sediments of Hanford age or as a pre-Missoula gravel (PNNL-14538). Less than 1 meter (3 feet) of Ringold Formation Unit A was encountered in the recently installed well, 299-E25-93, at approximately 11.6 meters (38 feet) below the top of the aquifer (WMP18472; PNNL-14538). No Lower Mud Unit was found above Unit A at this site. The Ringold Formation extends down to the basalt basement. The unconfined aquifer thickness is approximately 27 meters (89 feet).

The hydrogeoloic properties used to estimate the rate and direction of groundwater flow have been reported in PNNL-15070, PNNL-13023, and PNNL-14538. Although there are discrepancies in reported hydraulic conductivity values for the 200 East Area, recent data suggest the permeabilities in the lower Hanford formation gravels are higher than values ( 30.5 meters [100 feet] per day) based on conventional slug injection/withdrawal tests (PNNL-14538). Consequently, values of 1,981 meters (6,500 feet) per day from pumping tests for the area (PNL-8337; WHC-SD-EN-TI-019) are used to estimate the flow rate at this site. A more detailed discussion of the variability of hydraulic conductivity values can be found in PNNL-13023. 
Porosity is generally estimated to be about $30 \%$ for unconsolidated, coarse-grained sediments at the DOE Hanford Site (PNNL-13116). Because it has not been possible to collect intact core from the aquifer during past drilling, direct methods of determining porosity have not been used. The unconsolidated nature of the sediments combined with the presence of coarse sands and gravels comprising the aquifer suggests 30\% may be a reasonable estimate for effective porosity (Nielsen 1991; Dewan 1983). The local head difference between wells 299-E24-20 and 299-E25-93 is 0.000174 based on July 2004 water levels (PNNL-15070). July data, used for these analyses in fiscal year (FY) 2005, are not yet available.

The rate of groundwater flow is calculated for a homogeneous, isotropic aquifer using the Darcy equation (PNNL-13116). Incorporating the hydrogeologic properties presented above, an estimated flow rate varies from 0.85 to 1.16 meters (2.8 to 3.8 feet) per day. Estimates of the flow direction, based on well locations, water table elevations and in situ flow measurements, range from east southeast to southeast (PNNL 14187; PNNL 13023-ICN-1). Hydrographs, illustrating the local water level elevation differences, are shown in Figure 2.1. Well 299-E24-20 (in red) is upgradient while wells 299-E25-46, 299-E25-2 and 299-E25-93 (in blue) are downgradient. See Figure 1.2 for well locations. From FY 2003 to FY 2004, the drop in the water table was about 0.09 meter ( 0.3 foot). With a saturated screen interval ranging from 1.7 to 3.5 meters (5.6 to 11.5 feet) in the older RCRA network wells, some wells may eventually require replacing. However, the recently installed monitoring wells have screen thicknesses of close to 10.7 meters (35 feet). These wells will remain viable after the groundwater table stops declining. A more detailed discussion of hydrogeologic properties for this site can be found in PNNL-13023.

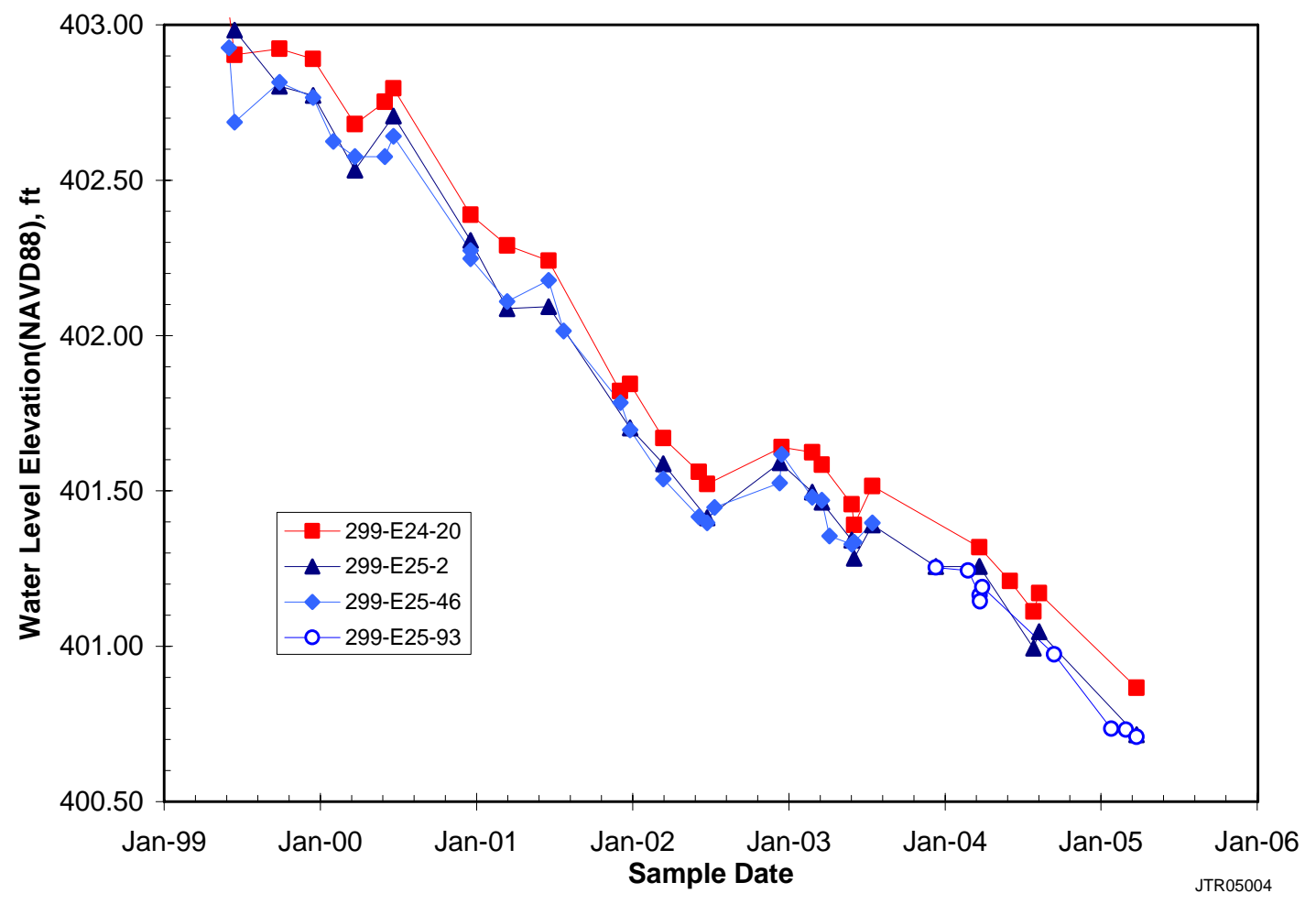

Figure 2.1. Hydrographs of Water Elevations at WMA A-AX. See Figure 1.2 for well locations. 


\subsection{Groundwater Chemistry}

The discussion in the following sections focuses on data related to the indicator parameters, exceedances of the critical mean for FY 2005, and historical trends of constituents controlling the specific conductance. A more complete discussion on groundwater chemistry for years prior to FY 2005 can be found in PNNL-15070, PNNL-14548, PNNL-14187, and PNNL-13788.

\subsubsection{Specific Conductance}

In accordance with the interim RCRA groundwater monitoring plan (PNNL-13023), wells were sampled semi-annually for groundwater contamination indicators (specific conductance, total organic carbon (TOC), $\mathrm{pH}$, and total organic halides) and site-specific parameters during FY 2005. For the current year (FY 2005), the upgradient/downgradient comparison value, or critical mean, used for statistical evaluations is $522 \mu \mathrm{S} / \mathrm{cm}$ for specific conductance. This value was $647 \mu \mathrm{S} / \mathrm{cm}$ in FY 2004; however, the inclusion of specific conductance data from a new upgradient well, 299-E24-22, lowered the critical mean for FY 2005.

The first semi-annual RCRA sampling event for FY 2005 was conducted in December 2004. A value of $535 \mu \mathrm{S} / \mathrm{cm}$ was observed at well 299-E25-93, a downgradient well installed in 2003 and located on the southeast corner of the 241-A Tank Farm (Figure 2.2). During January 2005, verification sampling at this well was performed, but the exceedance of the critical mean was not confirmed when a value of $506 \mu \mathrm{S} / \mathrm{cm}$ was found in the groundwater. The next regular semi-annual RCRA sampling event was in June 2005. Once again at downgradient well 299-E25-93, the critical mean was exceeded with a specific conductance value of $536 \mu \mathrm{S} / \mathrm{cm}$. Verification sampling was performed in July 2005. Results confirmed that the conductivity is above the critical mean with a value of $538 \mu \mathrm{S} / \mathrm{cm}$. These are the data that prompted placing WMA A-AX into RCRA assessment. Upgradient values ranged from 382 to $419 \mu \mathrm{S} / \mathrm{cm}$ for December 2004.

Well 299-E25-93 was initially sampled in December 2003 and showed elevated TOC for the first sampling event. The TOC value, averaged over four duplicate samples, was 3,600 $\mu \mathrm{g} / \mathrm{L}$, well over the FY 2004 critical mean of 2,360 $\mu \mathrm{g} / \mathrm{L}$ for this site. Results from verification sampling in March 2004 averaged $1,700 \mu \mathrm{g} / \mathrm{L}$, which, although below the critical mean, were above the limits of quantitation (LOQ) of 1,370 $\mu \mathrm{g} / \mathrm{L}$, indicating an organic compound may have existed. All other TOC data, both at this well and across the site, have been below the LOQ, past and present.

\subsubsection{Co-Varying Constituents}

Along with the elevated specific conductance in downgradient well 299-E25-93, the sulfate is elevated at $99 \mathrm{mg} / \mathrm{L}$, nitrate at $46 \mathrm{mg} / \mathrm{L}$, and technetium-99 at 5,540 pCi/L. The drinking water standard (DWS) is $250 \mathrm{mg} / \mathrm{L}$ for sulfate, $45 \mathrm{mg} / \mathrm{L}$ for nitrate, and $900 \mathrm{pCi} / \mathrm{L}$ for technetium-99. Upgradient the December 2004 sulfate values range from 59.1 to $65.2 \mathrm{mg} / \mathrm{L}$, the nitrate values range from 10.6 to 43.4 $\mathrm{mg} / \mathrm{L}$ while technetium-99 values range from 19 to $107 \mathrm{pCi} / \mathrm{L}$ (Figures 2.3 and 2.4). The sulfate concentrations dominate the specific conductance in well 299-E25-93, but the nitrate is above the DWS. 


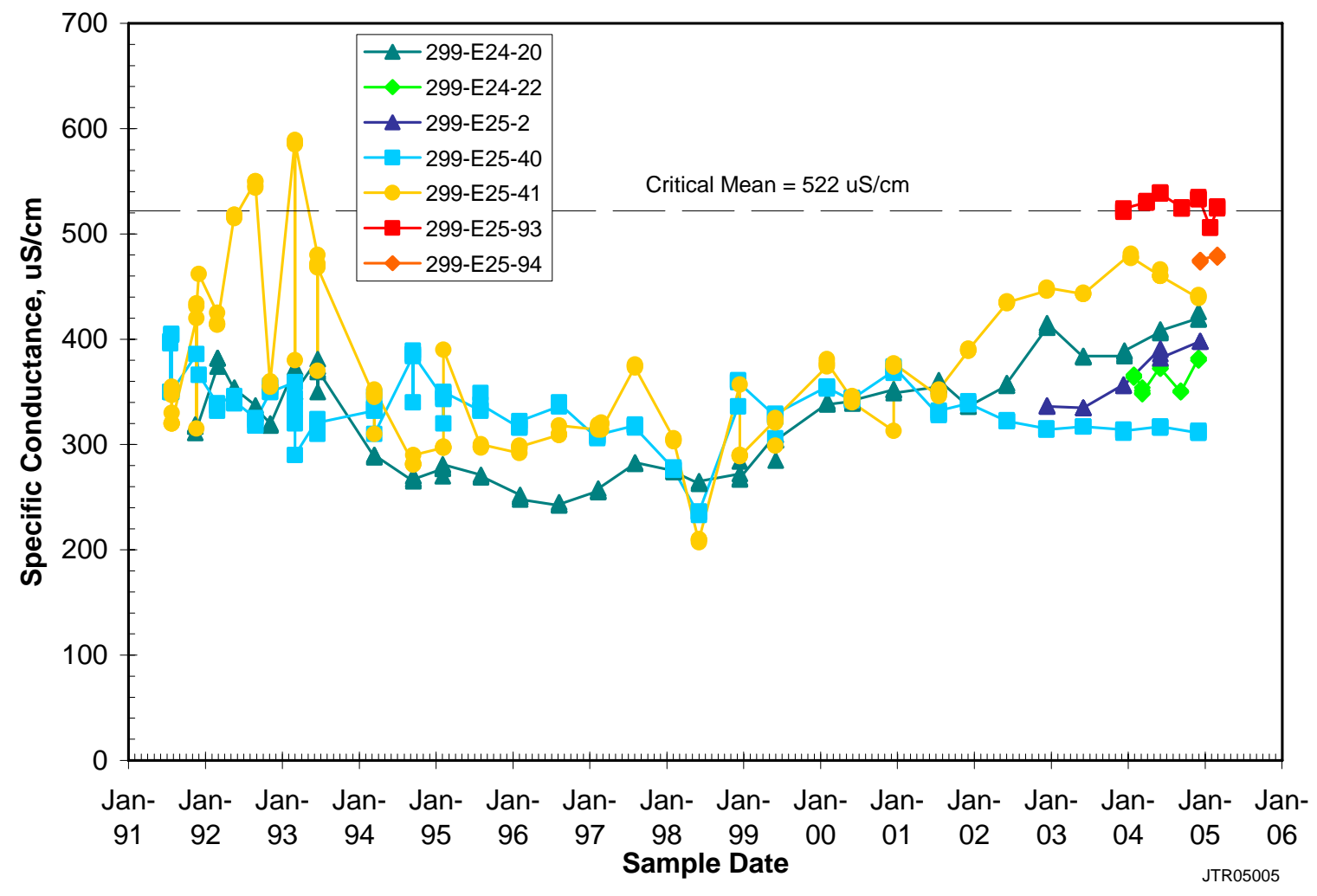

Figure 2.2. Time Series Trends of Specific Conductance in the Groundwater at WMA A-AX

These anions are the main source of the elevated specific conductance. The associated cations are primarily calcium and sodium. At well 299-E25-93, the December 2004 calcium concentration is $57 \mathrm{mg} / \mathrm{L}$ while the sodium value is $18.9 \mathrm{mg} / \mathrm{L}$. Upgradient these values range from 37.2 to $42.8 \mathrm{mg} / \mathrm{L}$ for calcium and from 18.3 to $19.1 \mathrm{mg} / \mathrm{L}$ for sodium.

At this time, the source or sources of these constituents are unknown. Although there appear to be regional upward trends of both sulfate and nitrate across large portions of the 200 East Area, the impact on groundwater at well 299-E25-93 cannot yet be determine because of insufficient data. With the addition of wells 299-E24-33 (upgradient) and 299-E25-94 (downgradient) contributing to the database beginning with FY 2005, a more complete picture of these constituents with relationship to both the tank farms and regional trends may develop with time.

\subsection{Conceptual Model of the Subsurface}

The purpose of the conceptual model is to explore the complexity and spatial/temporal relationships of three important parameters: contamination source, driving force, and migration pathway. Determinations of contaminant sources are facilitated by use of a conceptual model that integrates these three parameters. The model presented here includes the general waste chemistry and the tank farm settings, which incorporates the driving forces and migration pathways. In addition, the residual contaminant plumes in the soils along with the vadose zone migration pathway are qualitatively depicted. This discussion is summarized from PNNL-13023 where a more complete description can be found. 

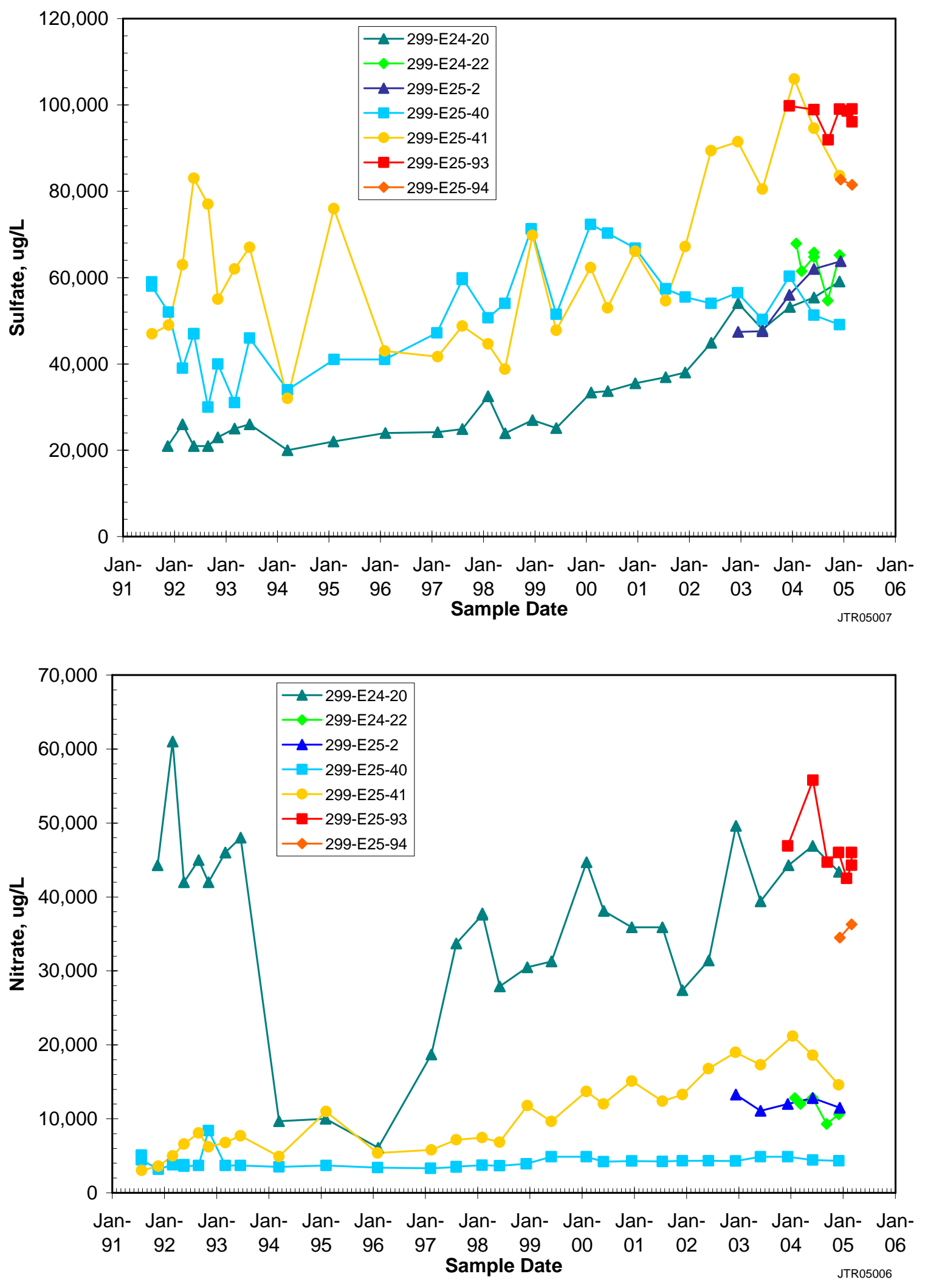

Figure 2.3. Time Series Trends of Sulfate and Nitrate in the Groundwater at WMA A-AX 


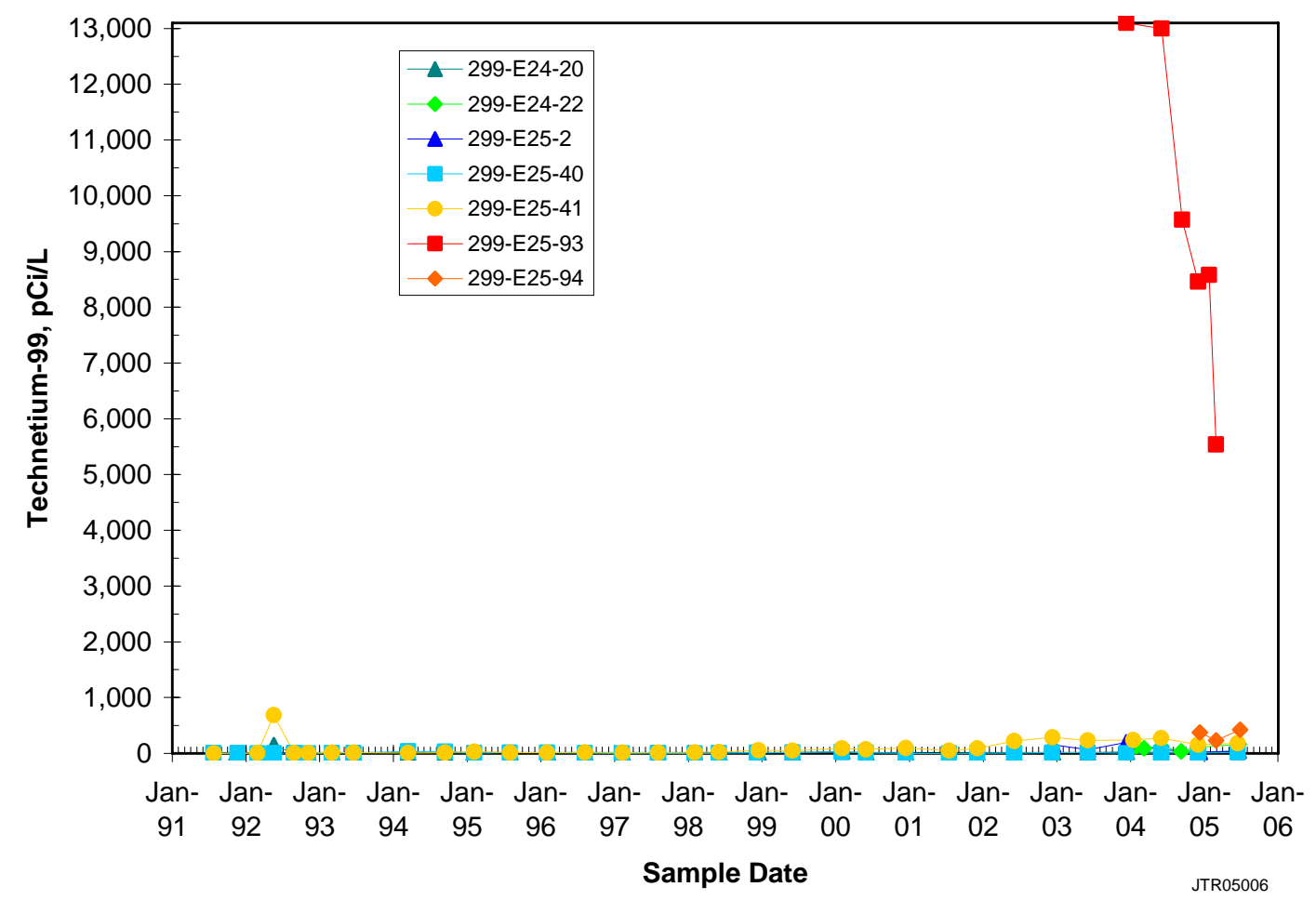

Figure 2.4. Time Series Trends of Technetium-99 in the Groundwater at WMA A-AX

\subsubsection{Contaminant Sources}

A graphical summary of the physical characteristics and mechanisms that could potentially affect the generation and transport of contamination at WMA A-AX to the groundwater is presented in Figure 2.4. Various possible contamination sources are shown. The red represents liquid waste at the time of an initial leak occurring from a tank, waste transfer line, or surface spill. The color shading, from red to orange to yellow, depicts contaminant migration since the initial leak to the present plume location in the vadose zone. The color change may represent either a chemical reaction of the waste with mineral phases in the soil or adsorption of relatively immobile waste constituents on to the soil grains leaving the mobile constituents dissolved in the pore water. Also shown is the interaction of fresh water migrating from the surface, moving the residual waste in the vadose zone plumes to the groundwater. This is shown as blue water interacting with residual yellow waste in the pore water to form migrating green waste. In this case, the residual contaminated soils act as a distinct and different source of contamination than the waste material in the tanks since the contamination in these soils is more readily available for migration to the groundwater.

In the following text, the sources of contamination in and around WMA A-AX and the surrounding facilities are discussed as they relate to this general conceptual model. The schematic depicts possible contamination sources in the vicinity of WMA A-AX. Viable migration pathways are shown that hazardous waste could take from a source to a monitoring well. Driving forces are also illustrated as the most likely mechanism for carrying tank-associated waste constituents through the vadose zone to the groundwater. 
Most tanks in WMA A-AX have no appreciable liquid left, and consequently there is little risk that new leaks could occur from these tanks. For example, in 1999, two tanks, 241-A-101 and 241-AX-101, contained significant volumes of liquids. The former had 2,729,282 liters (721,000 gallons) of drainable liquid while the latter contained 2,112,260 liters (558,000 gallons) (HNF-EP-0182-131). Most of these drainable liquids were removed to double-shell tanks over recent years. Currently, tank 241-A-101 contains 140,060 liters (37,000 gallons) while tank 241-AX-101 holds 166,558 liters (44,000 gallons) of interstitial liquid (HNF-EP-0182, Rev. 197). Consequently tank waste contamination in the groundwater should be related to either remobilization of residual vadose zone plumes or leaks associated with liquid waste transfers.

\subsubsection{Tank Leaks}

Some leaks at WMA A-AX appear to be related to tank construction. Apparently, these tanks leaked from failed welding joints at the heel of the tanks. Unlike the earlier 100-series tanks, which have rounded steel reinforcing "knuckles" connecting the tank wall to a dished base, the tanks at WMA A-AX have flat bottoms forming right angles at the welded heel joint. The concentration of stresses at the heel when the tanks were loaded and heated caused failure of the joints (WHC-SD-EN-AP-012). Waste from the Plutonium-Uranium Extraction (PUREX) Plant was discharged to the tanks as alkaline slurries with a $\mathrm{pH}$ of 9 or higher. Another site problem was corrosion at the liquid level of the waste residing in the tank. Other regions of failures are the joints where the intake/outtake lines or cascade lines were attached (WHC-SD-EN-AP-012). The effects of the various leak types are illustrated in Figure 2.4.

Of the 10 tanks located within the A-AX Tank Farms, five are confirmed or assumed leakers (HNF-EP-0182-131). A maximum leak volume of 1,120,481 liters (296,000 gallons) is reported for the WMA A-AX tanks. Small leaks (1892.7 to 30,283.3 liters [500 to 8,000 gallons]) have been reported for four of the tanks with the greatest volume leaked to the soil from tank 241-A-105 (37,854 to liters 1,048,559 [10,000 to 277,000 gallons]). These volumes do not include leaks from transfer lines, other ancillary equipment, surface spills or overflow amounts. Consequently, reported leak volumes must be considered a minimum of the total tank-related liquid released within the tank farm boundaries.

Although the most significant tank leak was from tank 241-A-105 when the bottom ruptured as a result of the 1965 steam explosion (WHC-MR-0264), gross gamma logs run in surrounding dry wells and laterals indicated that gamma-emitting radionuclides formed only low activity plumes in the soils under the tank (WHC-EP-0412). More recently, results from spectral gamma logs in dry wells near tank 241-A105 (DOE/GJO-HAN-110) indicate only moderate gamma-ray activity around this tank. There does not appear to be significant residual gamma-source waste left in the vadose zone at this single-shell tank farm to act as a source for groundwater contamination. However, the magnitude of the estimated inventory lost to the soil column and the structural history of the tank do not coincide with the logging result. It is unlikely that the logging results are incorrect, but contaminant migration pathways may be nearly vertical, thus, confining contamination to regions under or near the tank. Spectral gamma logging was also conducted to map vadose zone plumes at 241-AX Tank Farm (DOE/GJO-HAN-12). Results indicated that vadose zone plumes are small, isolated occurrences more likely caused by surface spills or small pipeline leaks. 


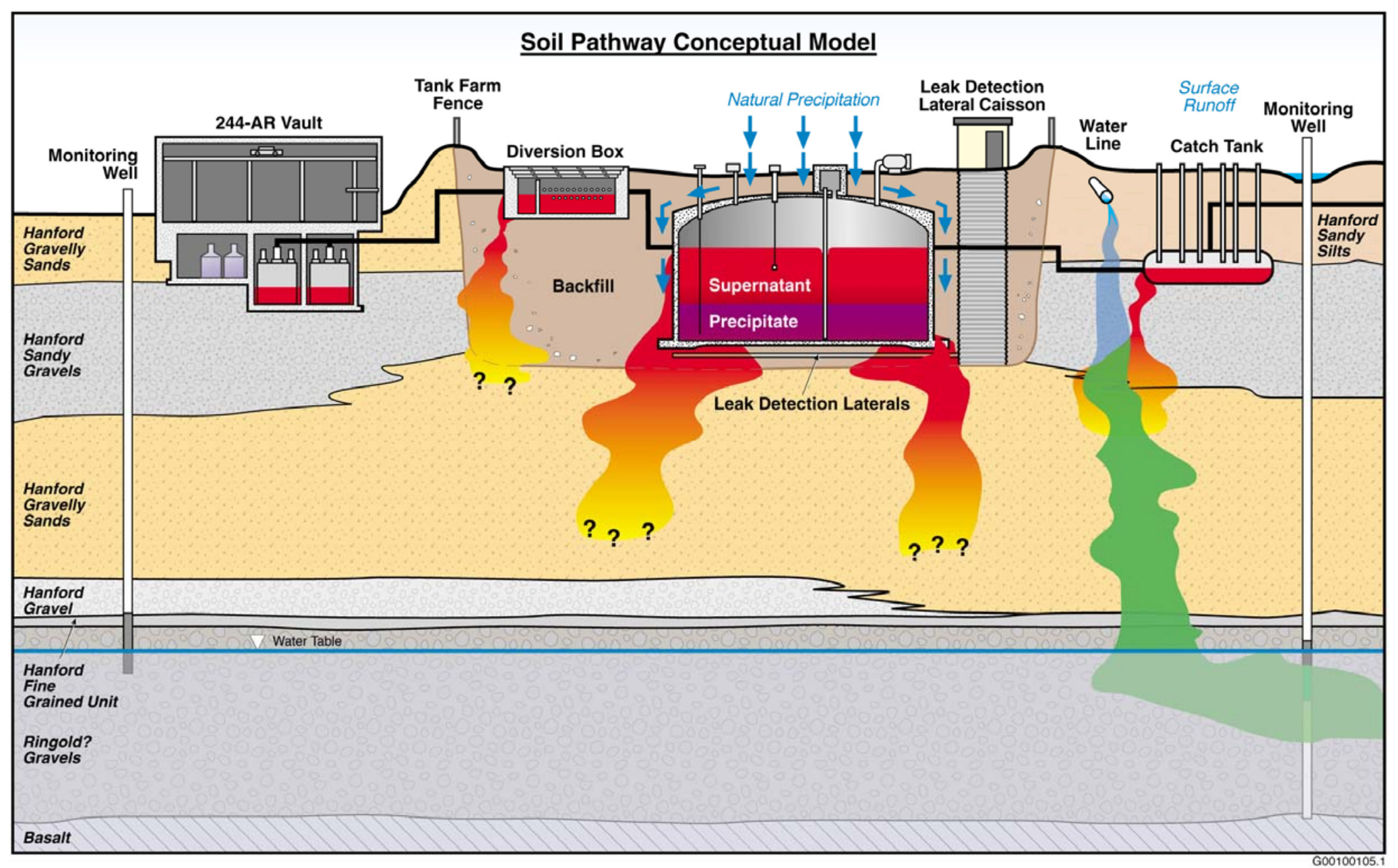

Figure 2.5. Conceptual Model for WMA A-AX. This schematic depicts possible contamination sources in the vicinity of WMA A-AX. Viable migration pathways are shown that hazardous wastes could take from a source to a monitoring well. Driving forces are also illustrated as the most likely mechanism for carrying tank-associated waste constituents through the vadose zone to the groundwater (after PNNL-13023). 
Migration of contamination by infiltrating surface water, however, could transport some of the mobile fraction of tank waste to groundwater, as illustrated by the transition from red/yellow to green under the catch tank in the conceptual model (Figure 2.4). Surface water leaks, spills, or ponded precipitation that encounter residual vadose zone waste in the pore liquids may cause this waste to move down in nearvertical, high permeability channels, spreading the contamination to new regions. Waste liquid with mobile constituents from this scenario would tend to have some lateral movement by capillary forces if fine-grained sedimentary layers such as silt-rich zones are encountered. With the discovery of perched water at depth in the recently drilled upgradient well 299-E24-33, lateral spreading could be a possible means of migration at this site.

\subsubsection{Non-Tank Sources}

Surface spills of waste liquids have occurred in the single-shell tank farms at various times in the past. The near surface contamination is probably associated with leaks from transfer lines, diversion boxes, catch tanks, and vaults. Given a sufficient driving force, any of these residual plumes could become a source for groundwater contamination.

In addition, there are liquid effluent disposal facilities surrounding the WMA. The cribs, trenches, and french drains were built to dispose of liquid waste directly to the soil column. Although the bulk of the disposed liquid was condensate and condenser cooling water, some depleted uranium waste, cell and stack drainage waste, and tributyl phosphate (TBP) kerosene organic waste from the PUREX Plant were also discharged to the soil column. The volumes of liquid effluent discharged to the various facilities ranged from as little as 6,056.7 liters (1,600 gallons) to as much as 1.15 billion liters (304 million gallons). The larger volumes are usually related to condensate from the various evaporation processes in use and result in waste with only low levels of dangerous waste components.

\subsubsection{Driving Forces}

In general, there are two ways that tank-associated waste can migrate to groundwater. Either the volume of the initial leak must be large enough to reach groundwater through gravity drive and/or capillary action, or an external source of water or other liquid must be available to remobilize a residual tank-associated vadose zone plume. Since most tanks in WMA A-AX no longer contain large amounts of liquid waste, it is unlikely that a tank could currently leak enough liquid to reach groundwater unassisted. However, a leaking waste transfer line during long-term waste removal operations could result in a substantial leak. Another way might be high pressure sluicing of a tank that already has a leak point developed.

Of these two scenarios, the easiest and most likely mechanisms for driving residual vadose zone contamination to the groundwater are external water sources. For example, a 2-inch raw water line broke in February 1978 on the east side of 241-A Tank Farm (WHC-SD-EN-AP-012). Before the line could be turned off, 227,124.7 liters (60,000 gallons) of water were released to the soil column. This large volume of water caused soil collapse in the center of the farm between tanks 241-A-102 and A-105, even though the ruptured line was on the east side of the farm.

Sources of water in the vicinity of the tanks can be either artificial (manmade) or natural. Examples of manmade water sources include nearby leaking or ruptured water lines, leaking fire hydrants or broken valves. A complex system of water and waste transfer lines exist within the farms to support farm 
operations. Failure of these pressurized lines, such as the February 1978 event, could result in driving tank waste to the groundwater.

Mobility of escaped waste can be increased as a result of natural recharge such as heavy rainfalls and sudden snowmelts. Johnson and Chou (1998) discuss in PNNL-11810 the extent that rapid snowmelt from recent years has contributed to natural driving forces. The results of a rapid snow melt event in February 1979 are documented in PNNL-11809 with photographs showing extensive flooding in the 241-T Tank Farm. The effects of these events can be enhanced by gravel surfaces, lack of plant uptake and transpiration, and surface depressions that tend to collect and pond run-off and snow melt.

\subsubsection{Migration Pathways}

The water table at WMA A-AX is approximately 88.4 meters (290 feet) bgs. Consequently, much of the migration pathway from the source to the groundwater monitoring well will be in the unsaturated zone. The nature of liquid migration through this zone is not well understood, but it is highly dependent on heterogeneities and anisotropy in the soil permeability. The bulk of the sediments are high-energy flood deposits with extreme variability in grain size over vertical and horizontal intervals on the order of tens of feet. Hydraulic conductivity values would be expected to change on at least the same scale if not less. Consequently, delineating migration pathways through a thick sequence of unconsolidated sediments is a challenging task.

In the 200 East Area, unsaturated sediments are primarily gravelly coarse-grained sands and sandy gravels with a few thin intermittent silt-rich units. Recently it has been shown that some of these lowpermeability horizons can cause significant perching of water thereby causing lateral spreading of infiltrating liquid (DOE/GJO-2002-343-TAR). For example, perched water was found at depth in the recently installed upgradient well 299-E24-33, located north of the 241-AY Tank Farm. A detailed stratigraphic description is provided in PNNL-13023 with cross-sections shown in Plates 1, 2, and 3.

As work progresses on the assessment investigations for the single-shell tank WMAs, more information has become available to further our understanding of migration pathways through both the vadose zone and the sediments in the unconfined aquifer. Impacts from various driving forces have also become better understood. Once a first determination at WMA A-AX is completed, this conceptual model may be revised to reflect new findings and the results of drilling the new monitoring wells. 


\subsection{Statement of Key Issues}

The vadose zone and groundwater underlying the 200 East Area have been contaminated by past disposal of liquid effluents that were primarily associated with chemical separation process. In the vicinity of WMA A-AX are past disposal units such as cribs, French drain, and areas of unplanned releases. In some cases, waste similar to that in the tanks was discharged to these facilities; therefore, the first determination of investigating groundwater quality conditions at WMA A-AX must investigate the basic question of whether or not the WMA is responsible for contributing dangerous waste or dangerous waste constituents to groundwater contamination. The DQO process, as described by EPA (2000) is used to design a cost efficient short-term sampling program, which includes review of existing data.

The fundamental issues for the ongoing groundwater investigation are:

- Is the contaminant pattern observed in key well 299-E25-93 consistent with flow from a single-shell tank source or is there an upgradient trend depicting a source other than single-shell tanks?

- Are dangerous waste or dangerous waste constituents from WMA A-AX compromising groundwater quality?

The decisions and associated information needs are discussed in Sections 4.0 and 5.0, respectively. 


\subsection{Decisions}

The decisions identified below are regulatory driven as stated in 40 CFR 265.93(d)(5), (6) and (7) [and by reference of WAC 173-303-400(3)] and as indicated in the Technical Enforcement Guidance Document (EPA 1986).

Key site-specific decisions, expressed as questions are listed below:

1. Are site-specific constituents consistent with the waste composition in WMA A-AX tank waste?

2. Are site-specific constituents observed in groundwater only downgradient from the WMA?

3. Are the number, location, and spacing of monitoring wells strategically located to detect contaminant plumes from the regulated unit?

4. Have dangerous waste or dangerous waste constituents from the facility entered the groundwater?

A flowchart that incorporates these decisions for the WMA A-AX assessment program is presented in Figure 4.1. Detailed summary of information needs, decision rules, and data collection design is presented in Section 5.0. The resulting sampling and analysis plan that bridges the gap between groundwater data obtained from earlier investigations under interim status indicator evaluation program and the information required to support decisions for the first determination is presented in Appendix A. 


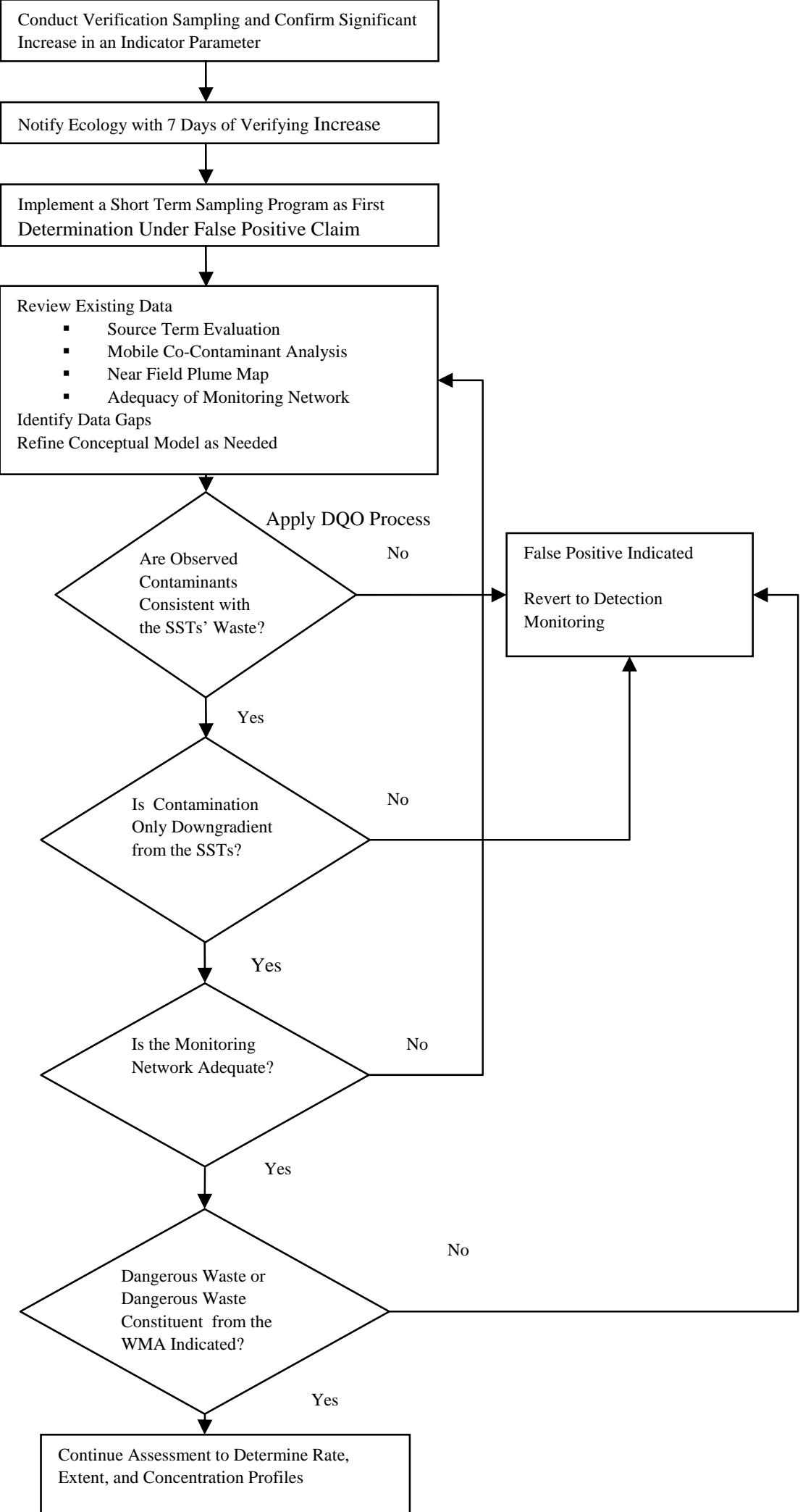

Figure 4.1. Flowchart Illustrating the DQO Decisions for the WMA A-AX Assessment Program 


\subsection{Information Needs and Decision Rules}

This section describes the information needs for addressing the general decisions and site-specific questions identified earlier. For discussion purposes, the information needs for WMA A-AX are organized by category as a statement highlighted in bold. Where appropriate, decision rules are provided.

\subsection{Characterization and Distribution of Contaminants}

The specific contaminants observed in the groundwater should reflect the source from which these constituents originally entered the subsurface. Although not always the case, mobile constituents can be expected to travel at the same rate through the vadose zone and subsequently the groundwater. Consequently there should be similar relative concentrations in the groundwater with respect to the source unless there have been contributions from multiple sources. In the case of WMA A-AX, the analytes causing the relatively high specific conductance at well 299-E25-93 should have co-varying mobile constituents indicative of waste from the WMA A-AX if the source is from the WMA.

Additionally the areal distribution of these specific constituents can provide evidence of migration through the groundwater with respect to potential source locations inside the WMA. Conversely, contaminant distributions may provide insight into movement of contaminants with regional extent that may be adversely affecting the groundwater quality observed downgradient. Thus, these information needs support both the first and second site-specific decisions required from the DQO process as delineated in Section 4.0 and required for a groundwater assessment first determination.

\subsubsection{Tank-Related Dangerous Waste Constituents}

The relationship between mobile tank-related dangerous waste constituents and contaminants observed in the groundwater needs to be assessed.

As previously indicated, distinguishing between contaminant suites related to tank waste and co-varying contaminants in the groundwater is fundamental to the identification of tank-sourced groundwater contamination from other sources. As found at other single-shell tank sites, pockets of contaminated soils left from previous unplanned events related to past tank farm activities or from events outside the farms are sources of groundwater contamination if clean water drivers are present. For example, water from either water line raptures/leaks or from natural precipitation events can carry vadose zone contaminants to groundwater. The chemistry of these events and those of surrounding waste discharge facilities should be studied and correlated to constituents observed in the groundwater. The answer may provide information concerning the nature of the source degrading the groundwater quality in the vicinity of WMA A-AX. 
The considerations discussed above lead to the following decision criteria:

- If mobile constituents with co-varying elements are consistent with waste sources found in the WMA storage facilities, from associated unplanned events or from contaminated soils within the farm boundaries, a tank-related source may be implied. If mobile constituents with co-varying elements are not consistent with tank-related sources, either currently stored in tank facilities or from past leak events, then a non-tank source is implied.

\subsubsection{Data Needs}

The data needed to resolve this issue are currently available in several documents on the chemistry used in the processes that generated the waste stored in the tanks at WMA A-AX. Furthermore the nature of the contaminants and co-varying constituents in the groundwater has a 15-year database for five of the wells used to monitor the site in the past but relatively few data exist for the newly installed wells, both upgradient and downgradient. Although there are some data on the key well 299-E25-93, installed in 2003, the approach will be to increase the sampling frequency, as required, to quarterly and after additional data are obtained, compare the results with tank waste constituents to answer the above decisions.

\subsubsection{Data Uses}

Results of this effort will be used to help answer the DQO question about how contaminants and co-varying constituents currently compromising groundwater quality relate to tank-associated waste.

\subsubsection{Areal Extent of Groundwater Contamination}

Determine whether the constituents causing the increased specific conductance at key well 299-E25-93 occur only in a location downgradient from single-shell tank WMA A-AX or are these contaminants and co-varying constituents located upgradient.

As noted above, a map of the concentrations of key constituents can provide insight relating to local sources of groundwater contamination. For example, if these constituents are observed downgradient from a facility at values significantly above upgradient values, a source or sources within the facility is implied. Conversely, if similar or higher values of contaminants are found upgradient with respect to levels observed in downgradient wells, the source of groundwater contamination is located upgradient from the facility.

\subsubsection{Data Needs}

The information required to prepare reliable concentration contours maps that include recently installed wells at WMA A-AX is not available over a sufficient time period in the historic groundwater chemistry database. Although there appear to be regional upward trends of both sulfate and nitrate across large portions of the 200 East Area, the impact on groundwater at key well 299-E25-93 cannot yet be determine because of insufficient data from this well and the other new wells. Additional groundwater chemistry data will be acquired to assess the impact if any, over a reasonable time period. 


\subsubsection{Data Uses}

The data from this type of mapping would delineate whether possible upgradient sources exist for the dangerous waste or dangerous waste constituents that may be compromising the groundwater quality at WMA A-AX. Conversely in the absence of evidence that upgradient sources may be causing the observed increases in specific conductance, a source within the single-shell tank farm facility is implied.

\subsection{Monitoring Well Network}

The number, location, and spacing of monitoring wells must be strategically located to delineate contaminant plumes coming from the regulated unit.

The adequacy of the monitoring well network to perform the above task was investigated in FY 2000 with a series of memo model studies to determine if waste from the 241-AX and 241-A Tank Farms could be detected (PNNL-13023). Based on the results of this investigation, it was recommended that two new upgradient wells and three new downgradient wells be installed to increase monitoring efficiency. A complete discussion of this process and results can be found in PNNL-13023 and PNNL-13023-ICN-1. During the time from FY 2001 to 2004 when three new monitoring wells (two upgradient and one downgradient) were installed, two older downgradient wells were removed from service and subsequently decommissioned per WAC 173-160-460. It had been determined, based on groundwater chemistry, that either the casing or steel screens were corroding in well 299-E24-19 (see Figure 1.2). This corrosion was confirmed with a borehole video survey performed in FY 2004. It was also found at that time that well 299-E25-46 also suffered from a corroded casing. Results were reported in PNNL-15070. A replacement well, 299-E25-94, was installed that same year.

To optimize the use of existing wells, a non-RCRA compliant well, 299-E25-2, located east of the 241-A Tank Farm and southeast of the 241-AX Tank Farm, was included in the downgradient network to effectively reduce the need from three to two new downgradient wells. Only one additional downgradient well, located south southeast of the 241-A Tank Farm, will be installed. After this well is drilled, the detection monitoring network outside the WMA will be complete and should be adequate to discern tank-related groundwater contamination from upgradient sources.

In the event that the first two decisions under Section 4.0 lead the investigation to consider the adequacy of the network or the site continues in assessment after the first determination investigation is complete, the monitoring network will be reevaluated. Based on the current groundwater chemistry observed in the downgradient wells, especially well 299-E25-93, it may be recommended that wells inside the single-shell tank facilities be monitored or additional assessment wells be installed. All decisions regarding installation of new wells will be coordinated with personnel at the 200-PO-1 Groundwater Operable Unit. However, with the recent extensive work that has been done to improve the monitoring network at WMA A-AX, additional work is not deemed necessary at this time, with the exception of installing the third downgradient well. This well is scheduled for installation in FY 2007. 


\subsection{Indication of Dangerous Waste or Dangerous Waste Constituents}

Based on results from the above steps, determine if dangerous Waste or Dangerous Waste Constituents from the waste management area are compromising groundwater quality.

The results of the previously described investigations along with the subsequent data collection and analyses provides the owner/operator of a facility the opportunity to determine whether dangerous waste or dangerous waste constituents from the regulated unit have compromised groundwater quality. Based on these results, if it is found that no dangerous waste or dangerous waste constituents from WMA A-AX have degraded the quality of the groundwater, the site will be reinstated to an indicator evaluation program (40 CFR 265.93(d)(6)]. If, however, the first determination confirms dangerous waste or dangerous waste constituents from the facility have compromised the groundwater quality, further assessment activities will be initiated under a separate plan to determine the rate, extent, and concentration of the migrating contaminants. Because this final step in the DQO process is based on the results of previous decisions, there are no data needs or specific data uses associated with this decision.

\subsection{Assessment Schedule}

A time frame for reaching a final decision about whether dangerous waste or dangerous waste constituents from tank farm operations contributed to the degradation of groundwater quality at WMA A-AX may be as short as 12 months from the release date of this document if the present-day trends in groundwater chemistry continue. However, as seen at other single-shell tank WMAs, once the sampling frequency and areal extent of monitoring is increased, our understanding of groundwater contamination can change such that a first determination requires additional time (PNNL-13023). The tasks of comparing tank source chemistry along with co-contaminants to the groundwater chemistry may be completed in FY 2006 along with determining the areal extent of constituents in the groundwater responsible for the elevated specific conductance observed at key well 299-E25-93. If no other issues arise at the WMA or in the groundwater, a first determination report may be issued at either the end of FY 2006 or in the first half of FY 2007. Once a first determination has been concluded, a decision on the status of WMA A-AX will be made. If it is decided that operations at the WMA are responsible for dangerous waste or dangerous waste constituents compromising groundwater quality, a further assessment to determine rate and extent of the contamination will be put in place, as required by 40 CFR 265.93(d)(7)(i). However, if it is determined that dangerous waste or waste constituents associated with farm operations have not compromised groundwater quality, the site will return to interim status indicator evaluation monitoring under RCRA regulations (40 CFR 265.93(d)(6) and by reference of WAC 173-303-400[3]). 


\subsection{References}

\section{Public Laws}

Resource Conservation and Recovery Act of 1976, as amended, Public Law 94-580, 90 Statute 2795, 42 USC 6901 et seq.

\section{Code of Federal Regulation}

10 CFR 962. "Byproduct Material.” Code of Federal Regulations. Available online at http://www.access.gpo.gov/nara/cfr/waisidx_02/10cfr962_02.html

40 CFR 265, Subpart F. "Interim Status Standards for Owners of Hazardous Waste Treatment, Storage, and Disposal Facilities." Code of Federal Regulations. Available online at

http://www.access.gpo.gov/nara/cfr/waisidx_04/40cfr265_04.html

\section{Federal Register}

51 FR 24504. 1986. EPA Clarification of Regulatory Authority Over Radioactive Mixed Waste.” Federal Register.

\section{Revised Code of Washington}

RCW 70.105, Revised Code of Washington, Title 70, Chapter 105. Hazardous Waste Management Act.

\section{Washington Administrative Code}

WAC 173-160-460. "What is the Decommissioning Process for Resource Protection Wells? Washington Administrative Code, Olympia, Washington.

WAC 173-303. “Dangerous Waste Regulations.” Washington Administrative Code, Olympia, Washington.

WAC 173-303-400. “Interim Status Facility Standards.” Washington Administrative Code, Olympia, Washington.

WAC 173-303-9905. “Dangerous Waste Constituent List.” Washington Administrative Code, Olympia, Washington.

\section{Others}

Chou CJ and VG Johnson. 1998. "Balancing CERCLA and Facility Operations: Application of the DQO Process at Hanford's Spent Nuclear Fuel Storage Basins," in Annual Proceedings of the Institute of Nuclear Materials Management, July 26 - 30, 1998, Naples, Florida.

Dewan JT. 1983. Essentials of Modern Open-Hole Log Interpretation. PennWell Publishing Company, Tulsa, Oklahoma. 
DOE/GJO-HAN-110. 1998. Tank Summary Data Report for Tank A-105. U.S. Department of Energy, Grand Junction Office, Grand Junction, Colorado.

DOE/GJO-HAN-12. 1997. AX Tank Farm Report. U.S. Department of Energy, Grand Junction Office, Grand Junction, Colorado.

DOE/GJO-2002-343-TAR. 2002. Hanford 200 Areas Spectral Gamma Baseline Characterization Project, 216-B-8 Crib and Adjacent Sites Waste Site Summary Report, prepared by S.M. Stoller Corp., U.S. Department of Energy, Grand Junction Office, Grand Junction, Colorado.

EPA. 1986. RCRA Groundwater Monitoring Technical Enforcement Guidance Document. U.S. Environmental Protection Agency, Washington, D.C.

EPA. 2000, as revised. Guidance for the Data Quality Objectives Process. EPA/600/R-96/055

(QA/G-4), U.S. Environmental Protection Agency, Washington, D. C.

HNF-EP-0182-131. 1999. Waste Tank Summary Report for Month Ending February 28, 1999.

BM Hanlon, Fluor Daniel Hanford, Inc., Richland, Washington.

HNF-EP-0182, Rev. 197. 2004. Waste Tank Summary Report for Month Ending September 30, 2004.

BM Hanlon, Fluor Daniel Hanford, Inc., Richland, Washington.

Nielsen DM. 1991. Practical Handbook of Ground-Water Monitoring. Lewis Publishers, Inc. Chelsea, Michigan.

PNL-83370. 1992. Summary and Evaluation of Available Hydraulic Property Data for the Hanford Site Unconfined Aquifer System. PD Thorne and DR Newcomer, Pacific Northwest National Laboratory, Richland, Washington.

PNNL-11809. 1998. Results of Phase I Groundwater Quality Assessment for Single-Shell Tank Waste Management Areas T and T-TX at the Hanford Site. FN Hodges, Pacific Northwest National Laboratory, Richland, Washington.

PNNL-11810. 1998. Results of Phase I Groundwater Quality Assessment for Single-Shell Tank Waste Management Areas S-SX at the Hanford Site. VG Johnson and CJ Chou, Pacific Northwest National Laboratory, Richland, Washington.

PNNL-13023. 2001. RCRA Groundwater Monitoring Plan for Single-Shell Tank Waste Management Area A-AX at the Hanford Site. SM Narbutovskih and DG Horton, Pacific Northwest National Laboratory, Richland, Washington.

PNNL-13023-ICN-1. 2002. RCRA Groundwater Monitoring Plan for Single-Shell Tank Waste Management Area A-AX at the Hanford Site, Interim Change Notice 1. SM Narbutovskih, Pacific Northwest National Laboratory, Richland, Washington.

PNNL-13116. Hanford Site Groundwater Monitoring for Fiscal Year 1999. MJ Hartman, LF Morasch, WD Webber (eds.), Pacific Northwest National Laboratory, Richland, Washington. 
PNNL-13788. Hanford Site Groundwater Monitoring for Fiscal Year 2001. MJ Hartman, LF Morasch, WD Webber (eds.), Pacific Northwest National Laboratory, Richland, Washington.

PNNL-14187. Hanford Site Groundwater Monitoring for Fiscal Year 2002. MJ Hartman, LF Morasch, WD Webber (eds.), Pacific Northwest National Laboratory, Richland, Washington.

PNNL-14548. Hanford Site Groundwater Monitoring for Fiscal Year 2003. MJ Hartman, LF Morasch, WD Webber (eds.), Pacific Northwest National Laboratory, Richland, Washington.

PNNL-14538. 2003. Borehole Data Package for RCRA Wells 299-E25-93 and 299-E24-22 at SingleShell Tank Waste Management Area A-AX, Hanford Site, Washington. BA Williams and

SM Narbutovskih, Pacific Northwest National Laboratory, Richland, Washington.

PNNL-15070. Hanford Site Groundwater Monitoring for Fiscal Year 2004. MJ Hartman, LF Morasch, WD Webber (eds.), Pacific Northwest National Laboratory, Richland, Washington.

RPP-14430. 2003. Subsurface Conditions Description of the C and A-AX Waste Management Area. MJ Wood, TE Jones, SM Narbutovskih, R Schalla, DG Horton, and BN Bjornstad, CH2M HILL Hanford Group, Inc., Richland, Washington.

WHC-EP-0412. 1991. Fate and Transport of Constituents Leaked from Tank 241-A-105. JA Caggiano, Westinghouse Hanford Company, Richland, Washington.

WHC-MR-0264. 1991. Tank 241-A-105 Leak Assessment. Westinghouse Hanford Company, Richland, Washington.

WHC-SD-EN-AP-012, Rev. 0. 1989. Interim-Status Groundwater Monitoring Plan for the Single-Shell Tanks. EJ Jensen, SP Airhart, MA Chamness, TJ Gilmore, DR Newcomer, and KR Oster, Westinghouse Hanford Company, Richland, Washington.

WHC-SD-EN-AP-012, Rev. 1. 1991. Interim-Status Groundwater Monitoring Plan for the Single-Shell Tanks. JA Caggiano and SM Goodwin, Westinghouse Hanford Company, Richland, Washington.

WHC-SD-EN-TI-019. 1992. Hydrogeologic Model for the 200 East Groundwater Aggregate Area. MP Connelly, JV Borghese, CD Delaney, BH Ford, JW Lindberg and SJ Trent, Westinghouse Hanford Company, Richland, Washington.

WMP-18472, Rev. 0. 2003. Calendar Year 2003 RCRA Groundwater Monitoring Well Summary Report. CR Martinez, Fluor Hanford, Richland, Washington.

WMP-26222. 2005. Borehole Summary Report for the Six CERCLA Wells Drilled in the 200-UP-1 and 200-ZP-1 Operable Units, and the Six RCRA Wells Drilled in the A-AX, B-BX-BY, and U WMA.

L Walker, Fluor Daniel Hanford, Richland, Washington. (in preparation) 


\section{Appendix A}

Sampling and Analysis Plan 


\section{Contents}

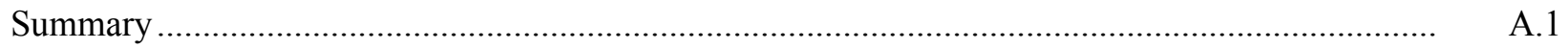

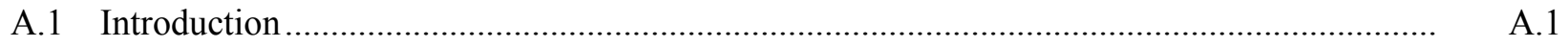

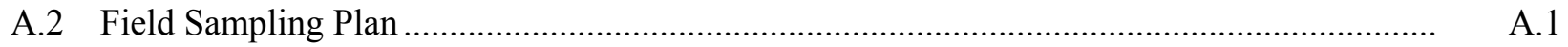

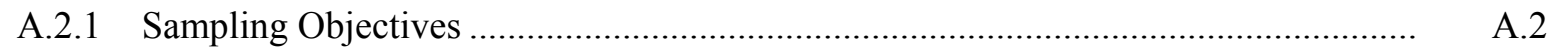

A.2.2 Site-Specific Waste Constituents ........................................................................... A. A.2

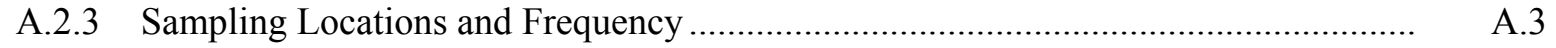

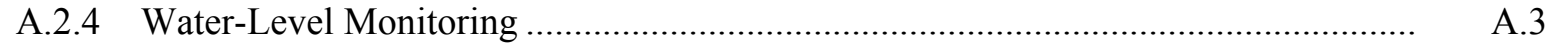

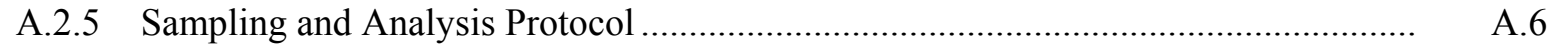

A.2.5.1 Scheduling Groundwater Sampling ......................................................... A.6

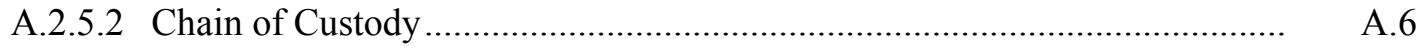

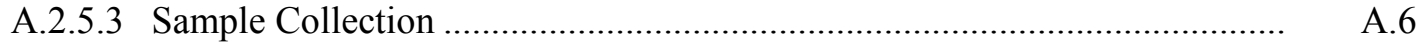

A.2.5.4 Analytical Protocols ............................................................................ A. A.7

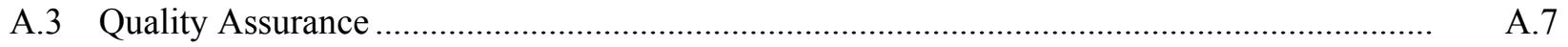

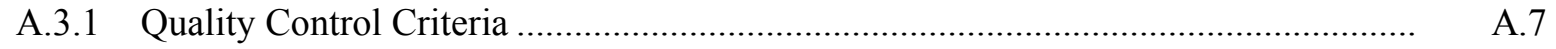

A.3.2 Groundwater Data Validation Process ................................................................... A.9

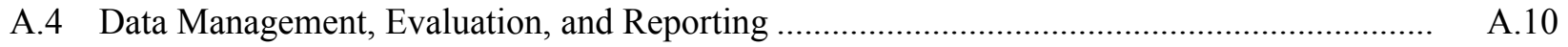

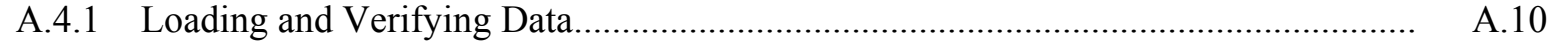

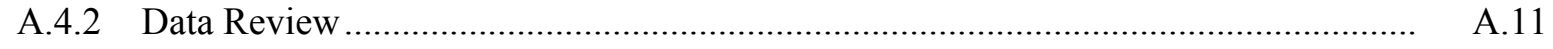

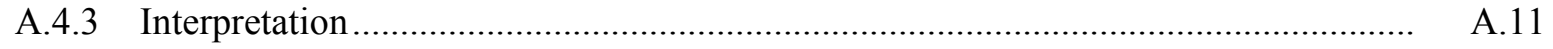

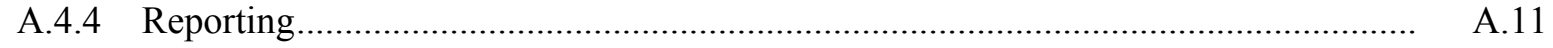

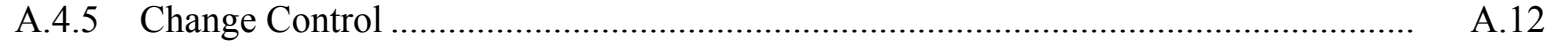

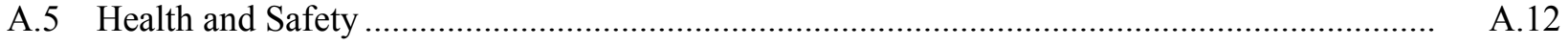

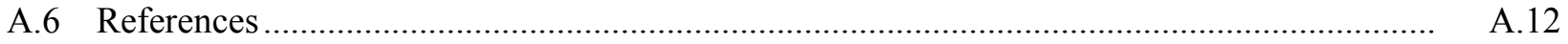




\section{Figure}

A.2.1 Location Map of Groundwater Monitoring Wells Around Waste Management

Area A-AX

\section{Tables}

A.2.1 Site-Specific Waste Constituent Group Along with Sampling Frequency........................ A.2

A.2.2 Groundwater Sampling Matrix for the WMA A-AX ..................................................... A.4

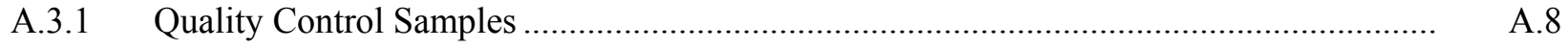

A.3.2 Recovery Limits for Double Blind Standards ….................................................. A.9

A.4.1 Change Control for Groundwater Monitoring in the WMA A-AX................................ A.12 


\section{Appendix A}

\section{Sampling and Analysis Plan}

\section{Summary}

This appendix describes groundwater sampling and analysis requirements for the first determination, as allowed under 40 CFR 265.93(d)(5), to determine whether dangerous waste and dangerous waste constituents from Waste Management Area (WMA) A-AX have compromised groundwater quality.

This sampling and analysis plan (SAP) describes the monitoring network, constituents, and sampling schedule based on the outcome of the data quality objectives (DQO) process (EPA 2000) and on previous plans (PNNL-13023). Eight wells will be sampled quarterly as part of the first determination investigation. If it is found that no dangerous waste or dangerous waste constituents from WMA A-AX have degraded the groundwater quality based on first determination results, the site will be reinstated to the indicator evaluation program [40 CFR 265.93(d)(6)] and sampling will be returned to a semiannual frequency. If, however, the first determination confirms that dangerous waste or dangerous waste constituents from the facility have compromised groundwater quality, further assessment activities will be initiated under a separate plan to determine the rate, extent, and level of contamination [40 CFR 265.93(d)(7)]. Site specific waste constituents are nitrate, sodium, sulfate, chromium, lead and total organic carbon. Samples will also be analyzed for additional constituents, including anions, metals and field parameters. Site specific waste constituents and co-varying elements are evaluated quarterly during the first determination, starting December 2005.

\section{A.1 Introduction}

The objective of this sampling and analysis plan is to provide the information required to support decisions for the first determination and continue building the groundwater database obtained under interim status indicator evaluation program. This plan describes the monitoring network, constituents, and schedule based on the outcome of the DQO process as described in the main text of this document and from information in the indicator program monitoring plan (PNNL-13023).

\section{A.2 Field Sampling Plan}

This section lists the wells to be monitored, the sampling frequency and the constituents. Protocol for sampling, analysis, and related activities are summarized. 


\section{A.2.1 Sampling Objectives}

The primary objective of assessment groundwater monitoring at the WMA A-AX is to provide data to assist the first determination investigations. For example, data will be collected to help determine whether the contaminant trends observed in key downgradient well 299-E25-93 are consistent with a single-shell tank source. Secondary objectives are to: (a) track concentration trends near the waste site, and (b) provide information on groundwater quality in the 200-PO-1 Groundwater Operable Unit.

\section{A.2.2 Site-Specific Waste Constituents}

The constituents that will be monitored at WMA A-AX for the assessment were determined based on the:

- Description of dangerous wastes in the Dangerous Waste Permit Application 88-21 Part A.

- Types and concentrations of constituents in the stored waste.

- Detectability of waste constituents in the groundwater.

- Concentrations or values of the monitoring parameters or constituents in the groundwater background chemistry.

Based on tank waste inventory as discussed in LA-UR-96-3860 and PNNL-13023, the major constituent groups along with sample frequency are presented in Table A.2.1. Site-specific waste constituents will be evaluated quarterly during the first determination. Additional constituents are monitored as supporting parameters. Section A.2.3 presents further information on constituents at each monitoring location.

Table A.2.1. Site-Specific Waste Constituent Group Along with Sampling Frequency

\begin{tabular}{|c|c|}
\hline Site-Specific Constituent Group & Sampling Frequency \\
\hline Anions & Quarterly \\
\hline ICP Metals & Quarterly \\
\hline Lead & Quarterly \\
\hline Alkalinity & Quarterly \\
\hline Total Organic Carbon & Quarterly $^{(a)}$ \\
\hline $\begin{array}{c}\text { Field Parameters/ } \\
\text { Supporting Constituents }\end{array}$ & Sampling Frequency \\
\hline $\mathrm{pH}$ & Quarterly $^{(a)}$ \\
\hline Specific Conductance & Quarterly $^{(a)}$ \\
\hline Technetium-99 & Quarterly \\
\hline Temperature & Quarterly \\
\hline Turbidity & Quarterly \\
\hline \multicolumn{2}{|c|}{ (a) Collect quadruplicate measurements during each sampling even } \\
\hline
\end{tabular}


The analysis for anions captures the values for nitrate and sulfate, which are the main mobile anionic species of concern found in these tanks. The analysis for metals provides concentrations for sodium and chromium, the main mobile cations of concern found in tank waste while lead requires a separate analytical technique. The organics listed in tank waste with the greatest concentrations are glycolate, dibutyl phosphate (DBP), ethylenediaminetetraacetic acid (EDTA), N-(2-hydroxyethyl) ethylenediaminetetraacetic acid (HEDTA), and butanol. The analysis for TOC is performed in quadruplicates to monitor for these organics. If results show an average value above the limit of quantitation for that sampling event, further analyses will be requested for specific organic constituents. Specific conductance and $\mathrm{pH}$ are collected in quadruplicate measurements to ensure data comparability with prior data.

\section{A.2.3 Sampling Locations and Frequency}

The WMA A-AX monitoring network includes three upgradient wells and five downgradient wells. The additional upgradient coverage, provided by newly installed wells 299-E24-22 and 299-E24-33, will assist in discriminating between contamination from tank-associated waste and contamination sourced from other waste storage facilities located upgradient of the site. One downgradient monitoring well is currently planned for installation south southeast of the 241-A Tank Farm in FY 2007 to complete basic coverage. Additional downgradient monitoring wells may be needed if results of the first determination indicate that dangerous waste or waste constituents from the WMA have compromised groundwater quality. The monitoring wells sampled in support of the WMA A-AX assessment are listed in Table A.2.2, and are located in Figure A.2.1. The table also includes constituents and frequency of sampling. Samples are collected in accordance with the procedures described in Section A.2.5.

\section{A.2.4 Water-Level Monitoring}

Groundwater levels are monitored on the Hanford Site primarily to help determine the direction and rate of groundwater flow. Static water levels are measured prior to sampling, and a minimum of two consistent measurements are taken to confirm precision of the measurement. A list of wells used for water-level measurements, criteria for their selection, hydrogeologic units monitored, and descriptions of the techniques used to collect the data are provided in Water-Level Monitoring Plan for the Hanford Groundwater Monitoring Project (PNNL-13021). The wells, identified in PNNL-13023, are used for annual measurements for WMA A-AX, taken in July each year when it is attempted to obtain all the measurements in a few hours to minimize possible barometric effects. Samplers measure depth to groundwater according to a subcontractor's procedure. The depth to groundwater is subtracted from the elevation of a reference point to obtain the water-level elevation above sea level.

Until recently, wells 299-E24-20, 299-E25-2, and 299-E25-46 were used to verify flow direction established with in situ measurements. The reference elevations for these wells are part of a common elevation survey. Thus, the problem of introducing an error by mixing references from multiple surveys is eliminated. Well 299-E25-46 was decommissioned in 2003. However, the recently installed well 299-E25-93 appears to be a viable substitute for the decommissioned well. A vertical survey indicates a deviation no more than 0.3 centimeter $(0.01$ foot) from the true vertical in the well. All newly installed wells have been surveyed for straightness. One well is off the vertical by over 44 centimeters ( 1.5 feet) and is not suitable for determining flow direction. At present, there is not enough data to evaluate the usefulness of the other newly installed wells. 
Table A.2.2. Groundwater Sampling Matrix for the WMA A-AX

\begin{tabular}{|c|c|c|c|c|c|c|c|c|c|c|c|c|c|c|c|c|}
\hline \multirow[b]{2}{*}{ Well ID } & \multirow[b]{2}{*}{ Well Name } & \multirow[b]{2}{*}{ Status } & \multirow[b]{2}{*}{ 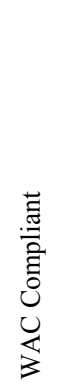 } & \multicolumn{6}{|c|}{ Site-Specific Constituents } & \multicolumn{7}{|c|}{ Supporting Constituents } \\
\hline & & & & 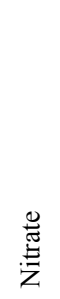 & 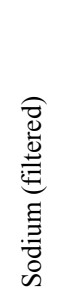 & 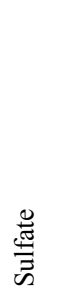 & 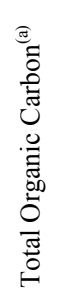 & 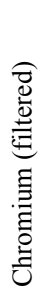 & 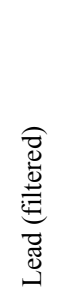 & 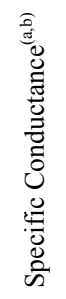 & 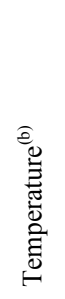 & 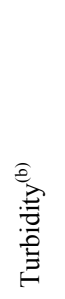 & 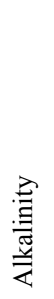 & 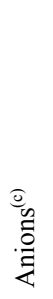 & 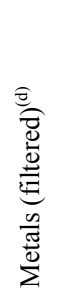 & 章 \\
\hline \multicolumn{17}{|c|}{ Wells } \\
\hline A4756 & 299-E24-20 & Active & $\mathrm{C}$ & Q & Q & Q & Q & Q & Q & Q & Q & Q & Q & Q & Q & Q \\
\hline $\mathrm{C} 4123$ & 299-E24-22 & Active & $\mathrm{C}$ & Q & Q & Q & Q & Q & Q & Q & Q & Q & Q & Q & Q & Q \\
\hline $\mathrm{C} 4257$ & 299-E24-33 & Active & $\mathrm{C}$ & Q & Q & Q & Q & Q & Q & Q & Q & Q & Q & Q & Q & Q \\
\hline 4789 & 299-E25-40 & Active & $\mathrm{C}$ & Q & Q & Q & Q & Q & Q & Q & Q & Q & Q & Q & Q & Q \\
\hline 4790 & 299-E25-41 & Active & $\mathrm{C}$ & Q & Q & Q & Q & Q & Q & Q & Q & Q & Q & Q & Q & Q \\
\hline 14766 & 299-E25-2 & Active & $\mathrm{N}$ & Q & Q & Q & Q & Q & Q & Q & Q & Q & Q & Q & Q & Q \\
\hline 4122 & 299-E25-93 & Active & $\mathrm{C}$ & Q & Q & Q & Q & Q & Q & Q & Q & Q & Q & Q & Q & Q \\
\hline 4665 & 299-E25-94 & Active & $\mathrm{C}$ & Q & Q & Q & Q & Q & Q & Q & Q & Q & Q & Q & Q & Q \\
\hline $\begin{array}{l}\text { Quadru } \\
\text { Field m } \\
\text { Anions } \\
\text { Metals } \\
\text { Well is } \\
\text { Well co } \\
\text { To be sa }\end{array}$ & $\begin{array}{l}\text { te measurements. } \\
\text { rement. } \\
\text { lalytes include but } \\
\text { alytes include but } \\
\text { tructed as a WAC } \\
\text { uction is not comp } \\
\text { led quarterly starti }\end{array}$ & $\begin{array}{l}\text { t limited to } \\
\text { limited to } \\
73-160, \text { Part } \\
\text { nt with WA } \\
\text { December } 2\end{array}$ & $\begin{array}{l}\text { e anc } \\
\text { nium } \\
\text { reso } \\
-160\end{array}$ & $\begin{array}{l}\text { ate. } \\
\text { iodium } \\
\text { rotect } \\
\text { Two }\end{array}$ & $\begin{array}{l}\text { vell. } \\
\text { urce pr }\end{array}$ & tion $\mathrm{r}$ & ireme & & & & & & & & & \\
\hline
\end{tabular}




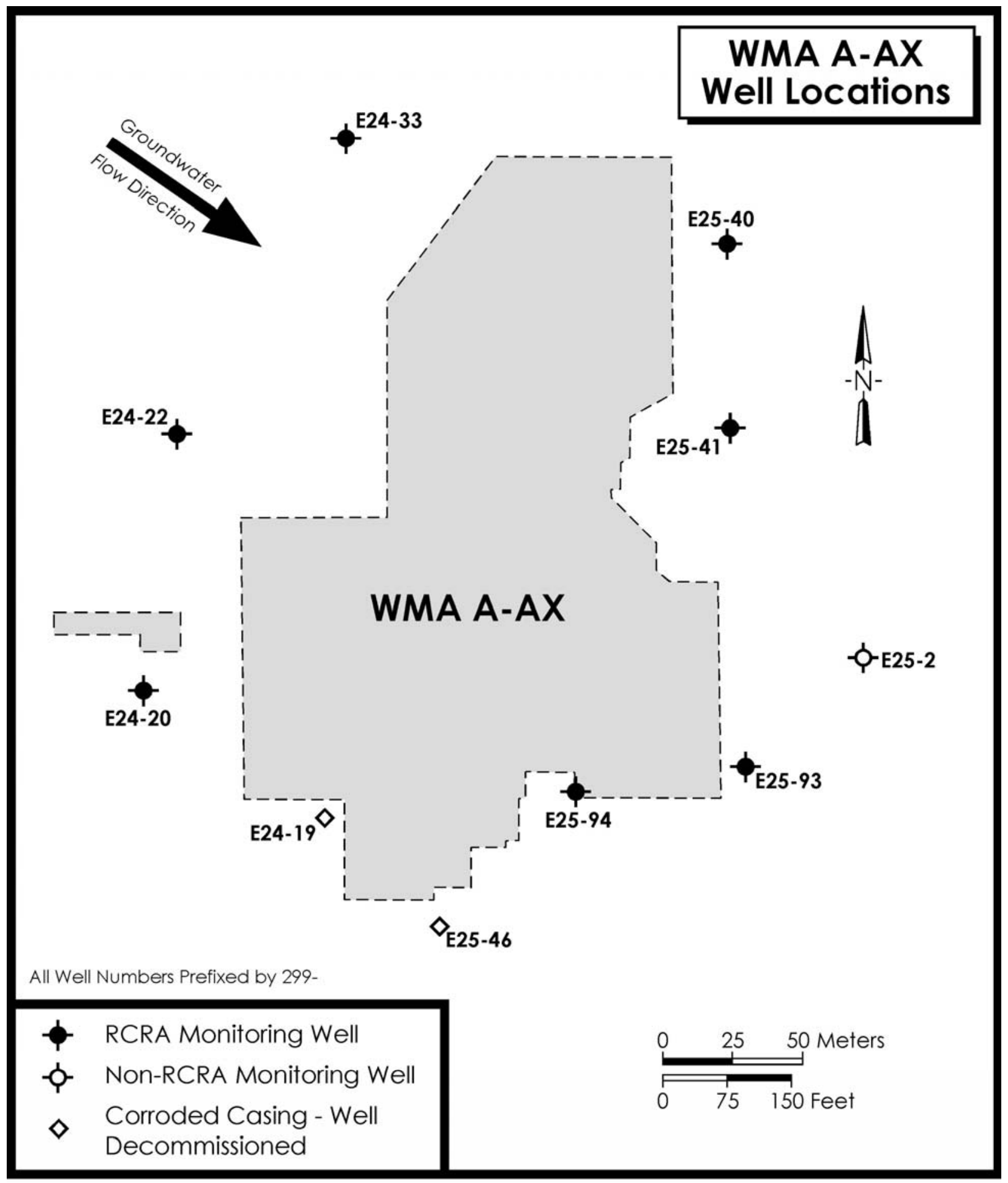

2005/DCL/A-AX/010 (10/14)

Figure A.2.1. Location Map of Groundwater Monitoring Wells Around Waste Management Area A-AX 


\section{A.2.5 Sampling and Analysis Protocol}

Groundwater monitoring for WMA A-AX is part of the Groundwater Performance Assessment Project (groundwater project) and follows the project's quality assurance plan, which is compliant with EPA Requirements for Quality Assurance Project Plans (EPA/240/B-01/003, EPA QA/R-5, March 2001, as revised). Groundwater monitoring will follow the requirements of the most recent revision of the quality assurance project plan. This monitoring plan need not be revised to cite future revisions of the quality assurance plan.

Project staff schedule sampling and initiate paperwork. The project uses subcontractors for sample collection, shipping, and analysis. Quality requirements for the subcontracted work are specified in statements of work or contracts.

The statement of work for sampling activities specifies that activities shall be in accordance with a quality assurance project plan that meets the requirements defined in Requirements for Quality Assurance Project Plans (EPA/240/B-01/003, EPA QA/R-5, 2001, as revised). Additional requirements are specified in the statement of work. Groundwater project staff conduct laboratory audits and field surveillances to assess the quality of subcontracted work and initiate corrective action if needed.

\section{A.2.5.1 Scheduling Groundwater Sampling}

The groundwater project has the responsibility for scheduling well sampling. Many wells are sampled for multiple objectives and requirements. Scheduling activities help manage the overlap, eliminating redundant sampling and meeting the needs of each sampling objective.

\section{A.2.5.2 Chain of Custody}

Pacific Northwest National Laboratory (PNNL) and the well sampling subcontractor use chain-ofcustody procedures and documentation that are consistent with Requirements for Quality Assurance Project Plans (EPA/240/B-01/003, EPA QA/R-5, March 2001, as revised). Use of these protocols documents the integrity of groundwater samples from the time of collection through data reporting. The forms are generated during scheduling (see Section A.2.5.1) and managed by the samplers.

\section{A.2.5.3 Sample Collection}

Groundwater samples are collected as described in a subcontractor procedure. Samples generally are collected after three casing volumes of water have been purged from the well or after field parameters ( $\mathrm{pH}$, temperature, specific conductance, and turbidity) have stabilized (i.e., after two consecutive measurements are within 0.2 units $\mathrm{pH}, 0.2^{\circ} \mathrm{C}$ for temperature, $10 \%$ for specific conductance, and turbidity $<5$ Nephelometric Turbidity Units [NTU]). For routine groundwater samples, preservatives are added to the collection bottles before their use in the field. Samples to be analyzed for metals are usually filtered in the field so that results represent dissolved metals. 


\section{A.2.5.4 Analytical Protocols}

Procedures for field measurements are specified in subcontractor's procedures. Each instrument is assigned a unique number that is tracked on field documentation and is calibrated and controlled according to procedure. Additional calibration and use instructions are specified in the instrument user's manuals.

Laboratory analytical methods are specified in contracts with the laboratories, and are standard methods from Test Methods for Evaluating Solid Waste: Physical/Chemical Methods (EPA SW-86, 1986, as revised) or Methods for Chemical Analysis of Water and Wastes (EPA 600/4-79-020, 1979, as revised).

\section{A.3 Quality Assurance}

The groundwater project's quality assurance plan is compliant with EPA Requirements for Quality Assurance Project Plans (EPA/240/B-01/003, EPA QA/R-5, March 2001, as revised). A quality control plan is included in the groundwater project quality assurance plan, and quality control sampling requirements for subcontracted work are discussed in a statement of work.

The groundwater project's quality control program is designed to assess and enhance the reliability and validity of groundwater data. This is accomplished through evaluating the results of quality control samples, conducting audits, and validating groundwater data. This section describes the quality control program for the entire groundwater project, which includes the WMA A-AX. The quality control practices of the groundwater project are compliant with the Tri-Party Agreement (Ecology et al. 1989, as amended), Section 7.8. Accuracy, precision, and detection are the primary parameters used to assess data. Data for these parameters are obtained from two categories of quality control samples: those that provide checks on field and laboratory activities (field quality control) and those that monitor laboratory performance (laboratory quality control). Table A.3.1 summarizes the types of samples in each category and the sample frequencies and characteristics evaluated.

\section{A.3.1 Quality Control Criteria}

Quality control data are evaluated based on established acceptance criteria for each quality control sample type. For field and method blanks, the acceptance limit is generally two times the instrument detection limit (metals), method detection limit (other chemical parameters), or minimum detectable activity (radiochemistry parameters). However, for common laboratory contaminants such as acetone, methylene chloride, 2-butanone, and phthalate esters, the limit is five times the method detection limit. Groundwater samples that are associated (i.e., collected on the same date and analyzed by the same method) with out-of-limit field blanks are flagged with a $\mathrm{Q}$ in the database to indicate a potential contamination problem. 
Table A.3.1. Quality Control Samples

\begin{tabular}{|c|c|c|}
\hline Sample Type & Primary Characteristics Evaluated & Frequency \\
\hline \multicolumn{3}{|c|}{ Field Quality Control } \\
\hline Full Trip Blank & Contamination from containers or transportation & 1 per 20 well trips \\
\hline Field Transfer Blank & Airborne contamination from the sampling site & $\begin{array}{l}1 \text { each day volatile organic compound } \\
\text { samples are collected }\end{array}$ \\
\hline Equipment Blank & $\begin{array}{l}\text { Contamination from non-dedicated sampling } \\
\text { equipment }\end{array}$ & 1 per 10 well trips or as needed ${ }^{(a)}$ \\
\hline Duplicate Samples & Reproducibility & 1 per 20 well trips \\
\hline \multicolumn{3}{|c|}{ Laboratory Quality Control } \\
\hline Method Blank & Laboratory contamination & 1 per batch \\
\hline Lab Duplicates & Laboratory reproducibility & Method/contract specific ${ }^{(b)}$ \\
\hline Matrix Spike & Matrix effects and laboratory accuracy & Method/contract specific ${ }^{(b)}$ \\
\hline Matrix Spike Duplicate & Laboratory reproducibility and accuracy & Method/contract specific ${ }^{(b)}$ \\
\hline Surrogates & Recovery/yield & Method/contract specific ${ }^{(b)}$ \\
\hline Laboratory Control Sample & Accuracy & 1 per batch \\
\hline Double Blind Standards & Accuracy and precision & Varies by constituent ${ }^{(\mathrm{c})}$ \\
\hline \multicolumn{3}{|c|}{$\begin{array}{l}\text { (a) When a new type of non-dedicated sampling equipment is used, an equipment blank should be collected every time } \\
\text { sampling occurs until it can be shown that less frequent collection of equipment blanks is adequate to monitor the } \\
\text { equipment's decontamination procedure. } \\
\text { (b) If called for by the analytical method, duplicates, matrix spikes, and matrix spike duplicates are typically analyzed at a } \\
\text { frequency of } 1 \text { per } 20 \text { samples. Surrogates are routinely included in every sample for most gas chromatographic methods. } \\
\text { (c) Double blind standards containing known concentrations of selected analytes are typically submitted in triplicate or } \\
\text { quadruplicate on a quarterly, semi-annual, or annual basis. }\end{array}$} \\
\hline
\end{tabular}

Field duplicates must agree within $20 \%$, as measured by the relative percent difference (RPD), to be acceptable. Only those field duplicates with at least one result greater than five times the appropriate detection limit are evaluated. Unacceptable field duplicate results are also flagged with a "Q" in the database.

For chemical analyses, the acceptance criteria for laboratory duplicates, matrix spikes, matrix spike duplicates, surrogates, and laboratory control samples are generally derived from historical data at the laboratories in accordance with Test Methods for Evaluating Solid Waste: Physical/Chemical Methods (EPA SW-86, 1986, as revised). Typical acceptance limits are within $25 \%$ of the expected values, although the limits may vary considerably with the method and analyte.

Table A.3.2 lists the acceptable recovery limits for the double-blind standards for selected WMA A-AX monitoring constituents. Double-blind standards of the constituents of concern are submitted to the primary laboratory in triplicate or quadruplicate on a quarterly basis. These samples are prepared by spiking background well water, as appropriate, with known concentrations of constituents of interest. Spiking concentrations range from the detection limit to the upper limit of concentration determined in groundwater on the Hanford Site. Double blind standard results that are outside the acceptance limits are investigated and appropriate actions are taken if necessary. Because the results of double-blind standards provide information on laboratory precision and accuracy, these standards are useful tools to verify that the project DQOs is being met. 
Table A.3.2. Recovery Limits for Double Blind Standards

\begin{tabular}{||l|c|c|c||}
\hline \multicolumn{1}{|c|}{ Constituent } & Frequency & Recovery Limits & Precision Limits (RSD) \\
\hline \hline Nitrate & Quarterly & $75-125 \%$ & $\pm 25 \%$ \\
\hline Sulfate & Quarterly & $75-125 \%$ & $\pm 25 \%$ \\
\hline Sodium & Quarterly & $75-125 \%$ & $\pm 25 \%$ \\
\hline Chromium & Annually & $80-120 \%$ & $\pm 20 \%$ \\
\hline Total Organic Carbon ${ }^{(a)}$ & Quarterly & Varies & Varies \\
\hline Specific Conductance & Quarterly & $75-125 \%$ & $\pm 25 \%$ \\
\hline Lead & Quarterly & $75-125 \%$ & $\pm 25 \%$ \\
\hline $\begin{array}{l}\text { (a) The spiking compound generally used is potassium phthalate. Other spiking compounds may also } \\
\text { be used. } \\
\text { RSD = Relative Standard Deviation }\end{array}$ \\
\hline
\end{tabular}

Holding time is the elapsed time period between sample collection and analysis. Exceeding recommended holding times could result in changes in constituent concentrations due to volatilization, decomposition, or other chemical alterations. Recommended holding times depend on the analytical method, as specified in Test Methods for Evaluating Solid Waste: Physical/Chemical Methods (EPA SW-86, 1986, as revised) or Methods for Chemical Analysis of Water and Wastes (EPA 600/4-79-020, 1979, as revised). Holding times are specified in laboratory contracts. Data associated with exceeded holding times are flagged with an " $H$ " in the Hanford Environmental Information System (HEIS) database.

Additional quality control measures include laboratory audits and participation in nationally based performance evaluation studies. The contract laboratories participate in national studies such as the EPAsanctioned water pollution and water supply performance evaluation studies. The groundwater project periodically audits the analytical laboratories to identify and solve quality problems or to prevent such problems. Audit results are used to improve performance. Summaries of audit results and performance evaluation studies are presented in the annual groundwater monitoring report.

\section{A.3.2 Groundwater Data Validation Process}

The groundwater project's data validation process provides requirements and guidance for validation of groundwater data that are routinely collected as part of the groundwater project. Validation is a systematic process of reviewing data against a set of criteria to determine whether the data are acceptable for their intended use. This process applies to groundwater data that have been verified (see Section A.4.1) and loaded into HEIS. The outcome of the activities described in the following paragraphs is an electronic data set with suspect or erroneous data corrected or flagged. Groundwater monitoring project staff document the validation process quarterly by signing a checklist, which is stored in the project file. 
Responsibilities for data validation are divided among project staff. Each groundwater interest area is assigned to a project scientist who is familiar with the hydrogeologic conditions of that site. The data validation process includes the following elements:

- Generation of data reports. Twice each month, data management staff provide tables of newly loaded data to project scientists for evaluation (biweekly reports). Also, after laboratory results from a reporting quarter have been loaded into HEIS, staff produce tables of water-level data and analytical data for wells sampled within that quarter (quarterly reports). The quarterly data reports include any data flags added during the quality control evaluation or as a result of prior data review.

- Project scientist evaluation. As soon as practical after receiving biweekly reports, project scientists review the data to identify changes in groundwater quality or potential data errors. Evaluation techniques include comparing key constituents to historical trends or spatial patterns. Other data checks may include comparison of general parameters to their specific counterparts (e.g., conductivity to ions) and calculation of charge balances. Project scientists request data reviews if appropriate (see Section A.4.2). If necessary, the laboratory may be asked to check calculations or re-analyze the sample, or the well may be resampled. After receiving quarterly reports, project scientists review sampling summary tables to determine whether network wells were sampled and analyzed as scheduled. If not, they work with other project staff to resolve the problem. Project scientists also review quarterly reports of analytical and water-level data using the same techniques as for biweekly reports. Unlike the biweekly reports, the quarterly reports usually include a full data set (i.e., all the data from the wells sampled during the previous quarter have been received and loaded into HEIS).

- Staff report results of quality control evaluations informally to project staff, DOE, and Washington State Department of Ecology each quarter; DOE will provide them to EPA on request. Results for each fiscal year are described in the annual groundwater monitoring report.

\section{A.4 Data Management, Evaluation, and Reporting}

This section describes how groundwater data are stored, retrieved, and interpreted.

\section{A.4.1 Loading and Verifying Data}

The contract laboratories report analytical results electronically and in hard copy. The electronic results are loaded into HEIS. Hard copy data reports and field records are maintained as part of the Tri-Party Agreement administrative record. Project staff perform an array of computer checks on the electronic file for formatting, allowed values, data flagging (qualifiers), and completeness. Verification of the hard copy results includes checks for (1) completeness, (2) notes on condition of samples upon receipt by the laboratory, (3) notes on problems that arose during the analysis of the samples, and (4) correct reporting of results. If data are incomplete or deficient, staff work with the laboratory to get the problems corrected. Notes on condition of samples or problems during analysis may be used to support data reviews (see Section A.4.2). 
Field data such as specific conductance, $\mathrm{pH}$, temperature, turbidity, and depth-to-water are recorded on field records. Data management staff enter these into HEIS manually through data-entry screens, verify each value against the hard copy, and initial each value on the hard copy.

\section{A.4.2 Data Review}

The groundwater project conducts special reviews of groundwater analytical data or field measurements when results are in question. Groundwater project staff document the process on review forms, and results are used to flag the data appropriately in HEIS. Various staff may initiate a review form: e.g., project scientists, data management staff, and quality control staff. A project scientist assigned to examine a review form determines and records the appropriate response and action on the review form, including changes to be made to the data flags in HEIS. Actions may include updating HEIS with corrected data or result of re-analysis, flagging existing data (e.g., "R" for reject, "Y" for suspect, "G" for good), and/or adding comments. Data management staff updates the temporary " $F$ " flag to the final flag in HEIS.

\section{A.4.3 Interpretation}

After data are validated and verified, the acceptable data are used to interpret groundwater conditions at the site. Interpretive techniques include:

- Hydrographs - graph water levels versus time to determine decreases, increases, seasonal, or manmade fluctuations in groundwater levels.

- Trend plots - graph concentrations of constituents versus time to determine increases, decreases, and fluctuations. May be used in tandem with hydrographs and/or water-table maps to determine if concentrations relate to changes in water level or in groundwater flow directions.

- Plume maps - map distributions of chemical in the aquifer to determine extent of contamination. Changes in plume distribution over time aid in determining movement of plumes and direction of flow.

- Contaminant ratios - can sometimes be used to distinguish between different sources of contamination.

\section{A.4.4 Reporting}

Chemistry and water-level data are reviewed after each sampling event and are available in HEIS.

Any unusual results for the WMA A-AX Unit will be summarized in letter reports or informal reports to Ecology (e.g., reports via e-mail or presented at meetings). Formal, interpretive reports for the entire Hanford Site are issued annually in March (e.g., Hanford Site Groundwater Monitoring for Fiscal Year 2003, PNNL-14548). 


\section{A.4.5 Change Control}

The approach to making changes in WMA A-AX monitoring activities, associated documents, and approval requirements are listed in Table A.4.1.

Table A.4.1. Change Control for Groundwater Monitoring in the WMA A-AX

\begin{tabular}{||l|l|l||}
\hline \multicolumn{1}{|c|}{ Type of Change } & \multicolumn{1}{|c|}{ Action } & \multicolumn{1}{c||}{ Documentation } \\
\hline \hline $\begin{array}{l}\text { Temporarily ( } \leq 1 \text { year) adding constituents, wells, } \\
\text { or increasing sampling frequency }\end{array}$ & $\begin{array}{l}\text { Project management approval; } \\
\text { notify regulator if appropriate }\end{array}$ & $\begin{array}{l}\text { Project's schedule tracking } \\
\text { system. }\end{array}$ \\
\hline $\begin{array}{l}\text { Permanently ( }>1 \text { year) adding constituents, wells, } \\
\text { or increasing sampling frequency }\end{array}$ & Revise assessment plan & $\begin{array}{l}\text { Revised plan or interim } \\
\text { change notice. }\end{array}$ \\
\hline $\begin{array}{l}\text { Deleting constituents or wells; decreasing } \\
\text { frequency }\end{array}$ & $\begin{array}{l}\text { Obtain regulator approval } \\
\text { prior to change. Revise } \\
\text { assessment plan. }\end{array}$ & $\begin{array}{l}\text { Initial approval may be verbal } \\
\text { or e-mail, followed by revised } \\
\text { plan or interim change notice. }\end{array}$ \\
\hline $\begin{array}{l}\text { Unavoidable changes (e.g., dry wells; delayed } \\
\text { samples, one-time missed samples due to broken } \\
\text { pump, lost bottle, etc.) }\end{array}$ & Notify regulator. & $\begin{array}{l}\text { Project's schedule tracking } \\
\text { system; notification via letter, } \\
\text { report, e-mail or meeting } \\
\text { minutes. }\end{array}$ \\
\hline Revision to sampling and analysis plan & $\begin{array}{l}\text { Revise plan; obtain regulator } \\
\text { approval; distribute plan. }\end{array}$ & Revised plan. \\
\hline
\end{tabular}

\section{A.5 Health and Safety}

All field operations will be performed consistent with PNNL health and safety requirements as described in PNNL's online Systems Based Management System. For work performed by other contractors, these standards are implemented via subcontracts and work orders.

Where necessary, work planning packages will include, as appropriate, a job hazard analysis, and/or a site-specific health and safety plan, and applicable radiological permits.

The sampling procedures and associated activities will implement as low as reasonably achievable practices to minimize radiation exposure to the sampling team, consistent with requirements outlined in accepted PNNL procedures.

\section{A.6 References}

40 CFR 265, Subpart F. "Interim Status Standards for Owners of Hazardous Waste Treatment, Storage, and Disposal Facilities." Code of Federal Regulations. Available online at http://www.access.gpo.gov/nara/cfr/waisidx_04/40cfr265_04.html 
Ecology - Washington State Department of Ecology, U.S. Environmental Protection Agency, and U.S. Department of Energy. 1989. Hanford Federal Facility Agreement and Consent Order. Document No. 89-10, as amended, (The Tri-Party Agreement), Olympia, Washington.

LA-UR-96-3860, Rev. 4. 1997. Hanford Tank Chemical and Radionuclide Inventories: HDW Model, SF Agnew, Los Alamos National Laboratory, Los Alamos, New Mexico.

EPA. 1979, as revised. Methods for Chemical Analysis of Water and Wastes. EPA-600/4-79-020, U.S. Environmental Protection Agency, Washington, D.C.

EPA. 1986, as revised. Test Methods for Evaluating Solid Waste: Physical/Chemical Methods, SW-846, Third Edition. Office of Solid Waste and Emergency Response, U.S. Environmental Protection Agency, Washington, D.C. Available online at: http://www.epa.gov/epaoswer/hazwaste/test/sw846.htm

EPA. 2000, as revised. Guidance for the Data Quality Objectives Process. EPA/600/R-96/055

(QA/G-4), U.S. Environmental Protection Agency, Washington, D.C. Available online at: http://www.epa.gov/quality1/qa_docs.html

EPA. 2001, as revised. EPA Requirements for Quality Assurance Project Plans. EPA/240/B-01/003/ (QA/R-5). U.S. Environmental Protection Agency, Washington, D.C. Available online at: http://www.epa.gov/quality1/qs-docs.html

PNNL-13023. 2001. RCRA Groundwater Monitoring Plan for Single-Shell Tank Waste Management Area A-AX at the Hanford Site. SM Narbutovskih and DG Horton, Pacific Northwest National Laboratory, Richland, Washington.

PNNL-14548. 2004. Hanford Site Groundwater Monitoring for Fiscal Year 2003. MJ Hartman, LF Morasch, and WD Webber (eds.), Pacific Northwest National Laboratory, Richland, Washington.

PNNL-13021. 1999. Water-Level Monitoring Plan for the Hanford Groundwater Monitoring Project. JP McDonald, MA Chamness, and DR Newcomer, Pacific Northwest National Laboratory, Richland, Washington.

WAC 173-160, Part Two. "General Requirements for Resource Protection Well Construction and Geotechnical Soil Borings.” Washington Administrative Code, Olympia, Washington. 


\section{Appendix B}

As-Built Diagrams of Groundwater Monitoring Wells at Waste Management Area A-AX 


\section{Appendix B}

\section{As-Built Diagrams of Groundwater Monitoring Wells at Waste Management Area A-AX}

The following as-built diagrams illustrate specifications of well construction and the general

lithologic information recorded during the drilling of each well. All depths and dimensions are in feet and inches, as they were recorded during the drilling and construction of the wells. Included are the eight wells in the current A-AX network. As-built diagrams for some newly installed are not available. However, well summary sheets, which have similar information, are substituted for these wells. Additional wells may be added to the network if results from the assessment investigation find it necessary. 


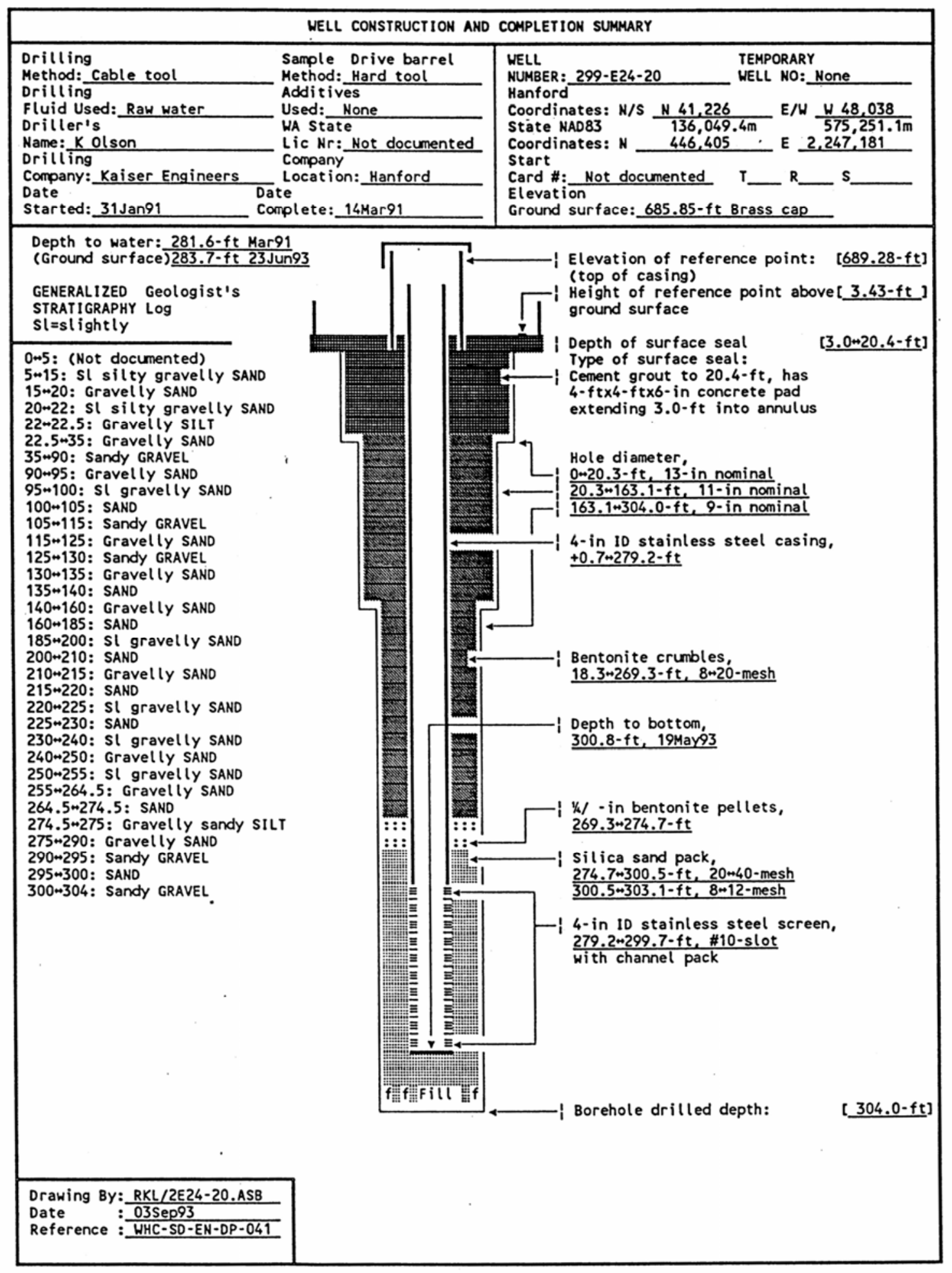




\section{SUMMARY OF CONSTRUCTION DATA AND FIELD OBSERVATIONS RESOURCE PROTECTION WELL - 299-E24-20}

WELL DESIGNATION
CERCLA UNIT
RCRA FACILITY
HANFORD COORDINATES
LAMBERT COORDINATES :
DATE DRILLED
DEPTH DRILLED (GS)
MEASURED DEPTH (GS)
DEPTH TO WATER (GS)
CASING DIAMETER
ELEV TOP CASING
ELEV GROUND SURFACE :
PERFORATED INTERVAL :
SCREENED INTERVAL
COMMENTS

AVAILABLE LOGS TV SCAN COMMENTS DATE EVALUATED EVAL RECOMMENDATION : LISTED USE CURRENT USER PUMP TYPE MAINTENANCE

299-E24-20

200 Aggregate Area Management Study Single Shell Tanks

N 41,226 W 48,038 [200E-24Śep91]

$N$ N 446,405 E 2,247,181 [HANCONV]

N 136,049.4m E 575,251.1m [NAD83-24Sep91]

Mar91

304.0-ft

Not documented

281.6- $\mathrm{ft}, 13 \mathrm{Mar} 91$;

283.7- $\mathrm{ft}$, 23Jun93

: $\quad 4-$ in stainless steel, $+0.7+279.2-\mathrm{ft}$;

6 -in stainless steel, $+3.4-0.5-\mathrm{ft}$

689.28-ft, [NGVD'29-24Sep91]

$685.85-\mathrm{ft}$, Brass cap [NGVD'29-24Sep91]

Not applicable

279.2-299.7-ft, 4-in \#10-slot stainless steel, with channel pack FIELD INSPECTION, 19May93;

4 and 6 -in stainless steel casing.

4- $\mathrm{ft}$ by $4-\mathrm{ft}$ concrete pad, 4 posts, 1 removable.

Capped and locked, brass cap in pad with well io.

Not in radiation zone.

OTHER:

Geologist, driller

Not applicable

Not apolicable

Not applicable

SST monthly water level measurement, 01Jun91-23Jun93;

WHC ES\&M W/l monitoring and RCRA sampling,

Hydrostar 


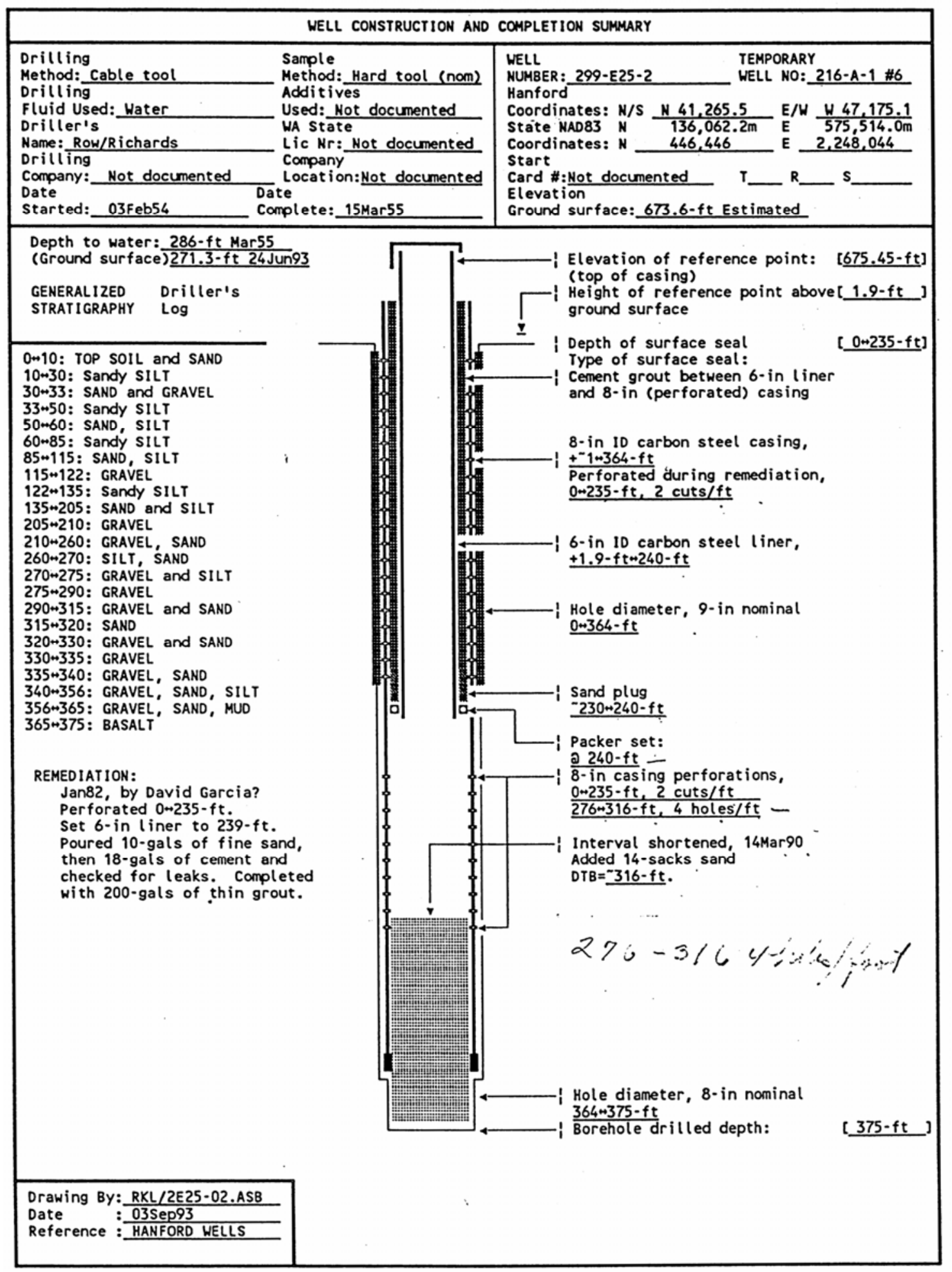




\section{SUMMARY OF CONSTRUCTION DATA AND FIELD OBSERVATIONS RESOURCE PROTECTION WELL - 299-E25-2}

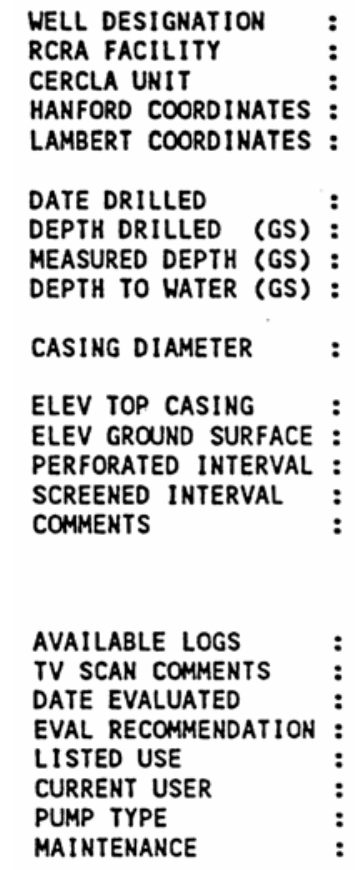

299-E25-2

Not applicable

200 Aggregate Area Management Study

N $41,265.5$ W $47,175.1$ [17Sep90-200E]

$N 446,446$ E 2,248,044 [HANCONV];

N 136,062.2m E $575,514.0 \mathrm{~m}$ [17Sep90-NAD83]

Mar55

375- $\mathrm{ft}$

Not documented

286-ft, Mar55;

271.3-ft, 24Jun93

$8-$ in, carbon steel, " $+1+364-\mathrm{ft}$;

6-in, carbon steel, $+1.9+240-f t$

$675.45-\mathrm{ft}$, [17Sep90-200E]

673.6- $\mathrm{ft}$, Estimated

$0+235$ and $276+316-\mathrm{ft}$

Not applicable

FIELD INSPECTION, 13May91.

6 and 8-in carbon steel casing. Capped and locked

No pad, no posts. no permanent identification.

In surface radiation zone.

Driller

Not applicable

Not applicable

Not applicable

SST monthly water level measurement, 29Mar56+24Jun93;

WHC ES\&M W/l monitoring,

Electric submersible.

14 Mar90 - Added 14 sacks sand. DTB=317.8- $\mathrm{ft}$ (TOC). 


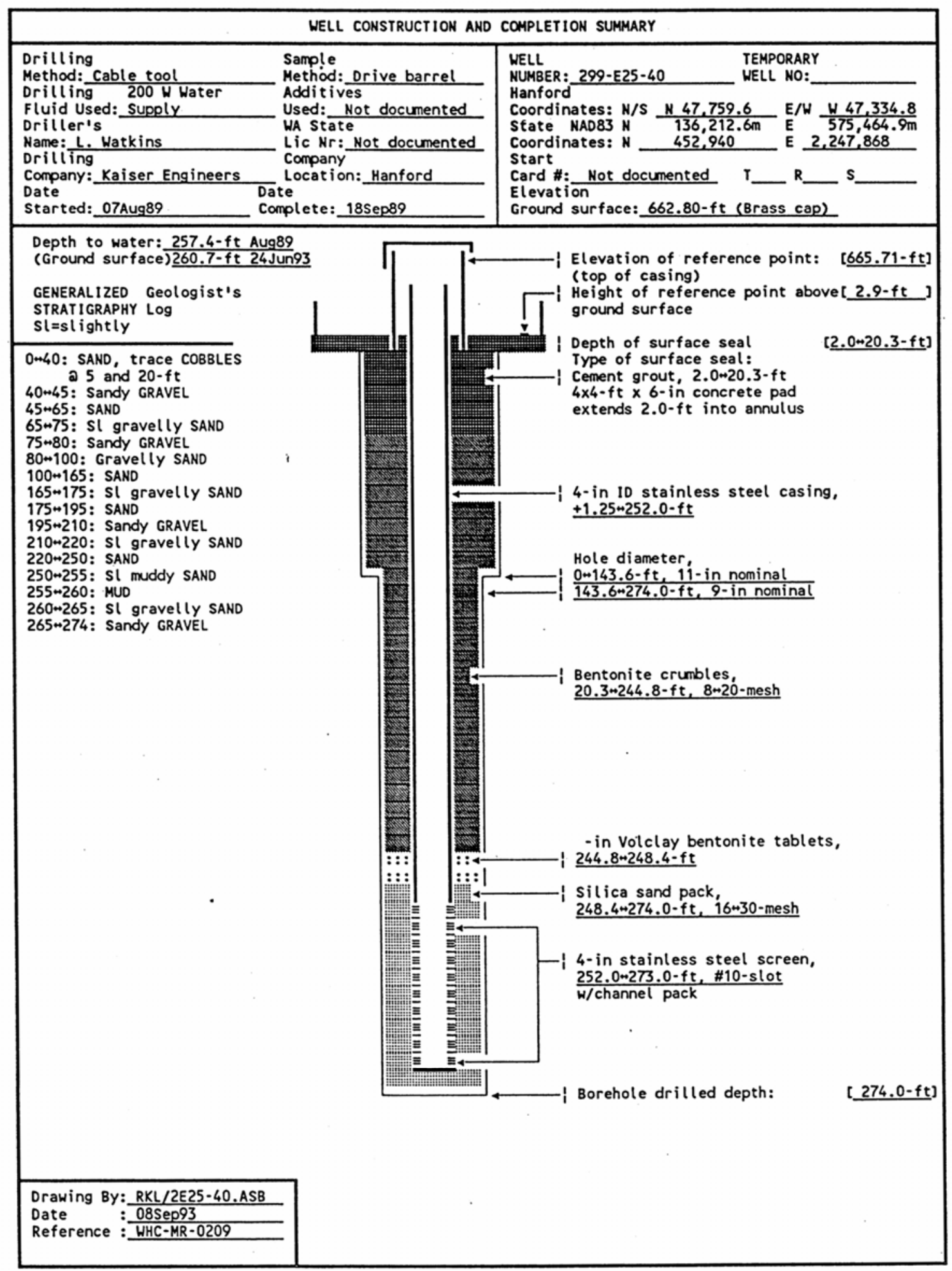




\section{SUMMARY OF CONSTRUCTION DATA AND FIELD OBSERVATIONS RESOURCE PROTECTION WELL - 299-E25-40}

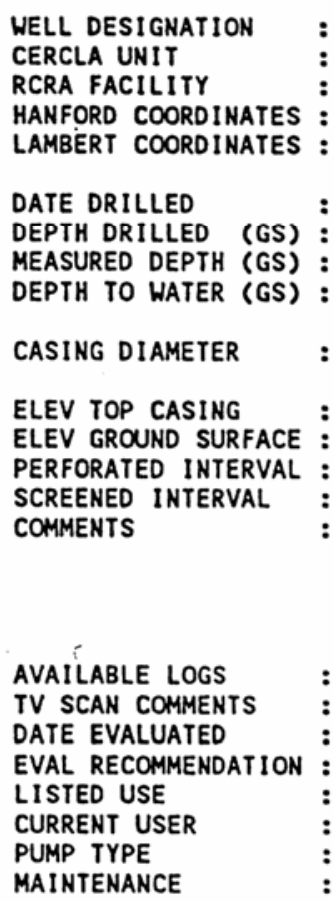

299-E25-40

200 Aggregate Area Management Study SST IMA A-AX, 241-AX Tank Farm

N $47,759.6$ W $47,334.8$ [04Jañ90-200E]

N 452,940 E 2,247,868; [HANCONV]

N 136,212.6m E $575,464.9 \mathrm{~m}$ [04Jan909-NAD83]

Sep89

274.0- $\mathrm{ft}$

Not documented

257.4-ft, 31Aug89:

260.7-ft, 24Jung

4 -in stainless steel, +1.25-252.0-ft;

6 -in stainless steel, +2.90 $0.5-\mathrm{ft}$

$665.71-\mathrm{ft}$, [04Jan90-200E]

$662.80-\mathrm{ft}$, Brass cap [04 Jan90-200E]

Not apol icable

252.0 $273.0-\mathrm{ft}, 4-$ in \#10-slot stainless steel w/channel pack FIELD INSPECTION, 02Feb90;

Stainless steel casing. $4-\mathrm{ft}$ by $4-\mathrm{ft}$ concrete pad, 4 posts, 1 removable capped and locked, brass cap in pad with well ID.

Not in radiation zone.

OTHER :

Geologist, driller

Not applicable

Hot applicable

Not applicable

SST monthly water level measurement, 010ec89m24Jun93;

WHC ES\&M w/l monitoring and RCRA sampling

Hydrostar 


\begin{tabular}{|c|c|c|c|c|}
\hline \multicolumn{5}{|c|}{ WELL CONSTRUCTION AND COMPLETION SUMMARY } \\
\hline $\begin{array}{l}\text { Drilling } \\
\text { Method: Cable tool } \\
\text { Drilling } 200 \text { W Water } \\
\text { Fluid Used: Supply } \\
\text { Driller's } \\
\text { Name: C. Whamsley } \\
\text { Drilling } \\
\text { Company: Kaiser Engineers } \\
\text { Date } \\
\text { Started: OsAug89 } \\
\text { Date }\end{array}$ & \multicolumn{3}{|c|}{$\begin{array}{l}\text { Sample Drive barrel } \\
\text { Method: Hard tool } \\
\text { Additives } \\
\text { Used: } \text { None } \\
\text { WA State } \\
\text { Lic Nr: Not documented } \\
\text { Company } \\
\text { Location: Hanford } \\
\text { ite } \\
\text { mplete: 22Sep89 }\end{array}$} & $\begin{array}{l}\text { WELL } \\
\text { NUMBER:_299-E25-41 }\end{array}$ \\
\hline \multicolumn{4}{|l|}{$\begin{array}{l}\text { Depth to water: } \frac{262.2-\mathrm{ft} \operatorname{Sep} 89}{262.0-\mathrm{ft} 19 \mathrm{Aug}^{\circ} 93} \\
\text { (Ground surface) }\end{array}$} & $\begin{array}{l}\text { i Elevation of reference point: }[671.26-\mathrm{ft}] \\
\text { (top of casing) } \\
\text { i Height of reference point above }[3.2-\mathrm{ft}] \\
\text { ground surface }\end{array}$ \\
\hline 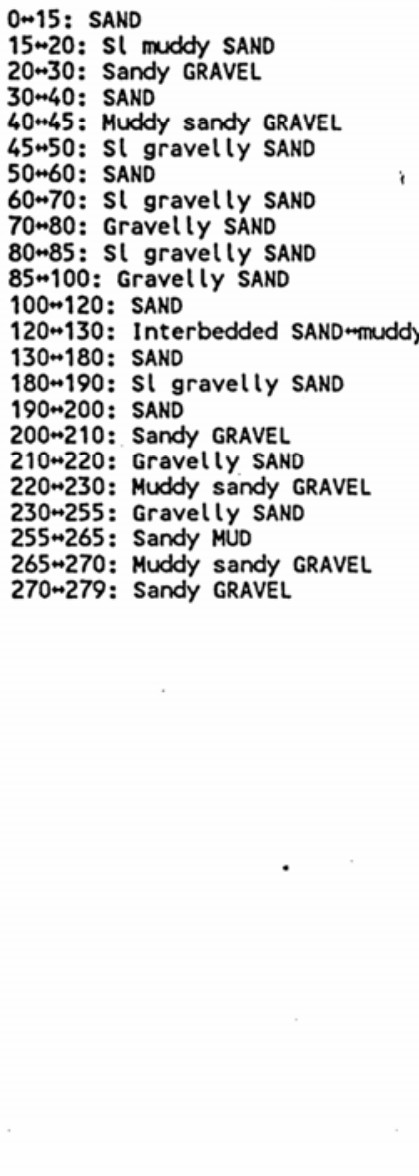 & dy SAND & 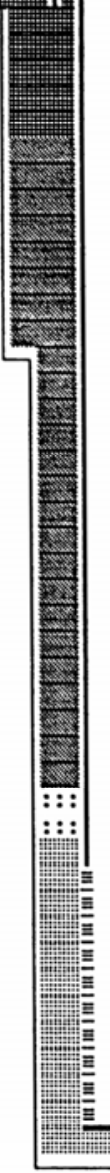 & 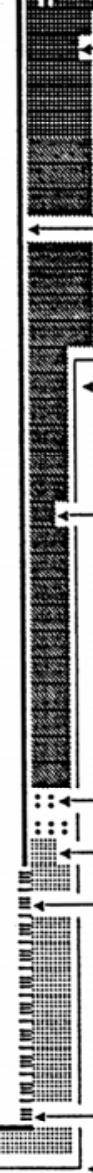 & 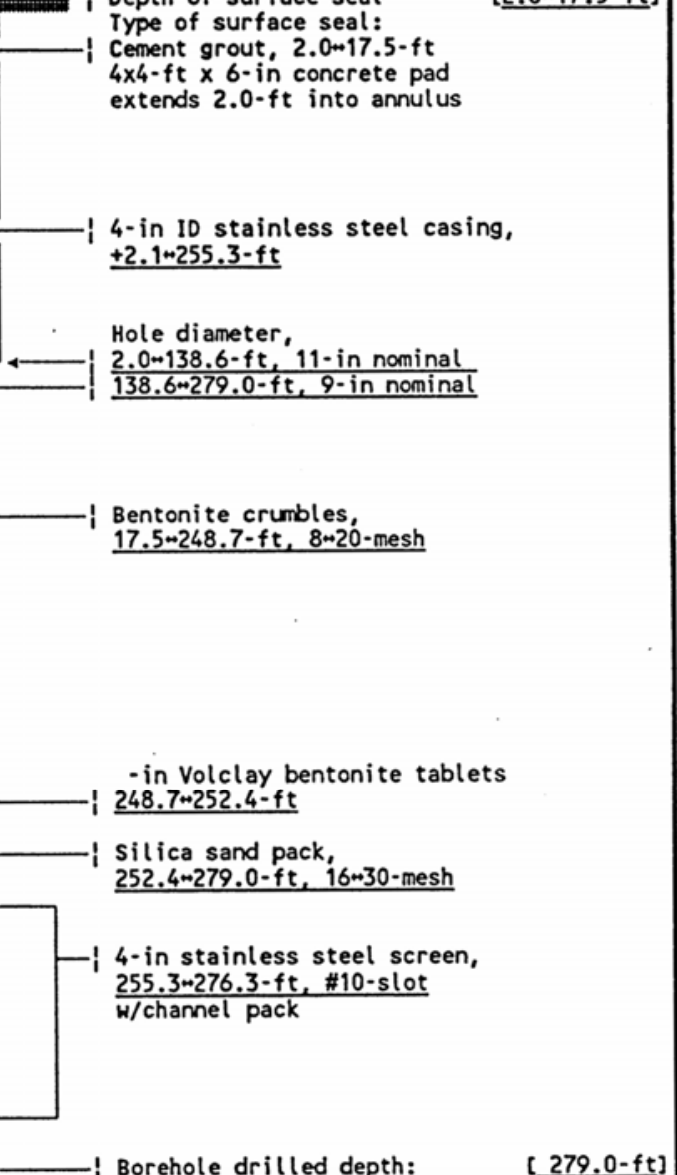 \\
\hline $\begin{array}{ll}\text { Drawing By: } & \text { RKL/2E25-41.ASB } \\
\text { Date } & \text { 08Sep93 } \\
\text { Reference }: & \text { WHC-MR-0209 }\end{array}$ & & & $:$ & \\
\hline
\end{tabular}




\section{SUMMARY OF CONSTRUCTION DATA AND FIELD OBSERVATIONS RESOURCE PROTECTION WELL - 299-E25-41}

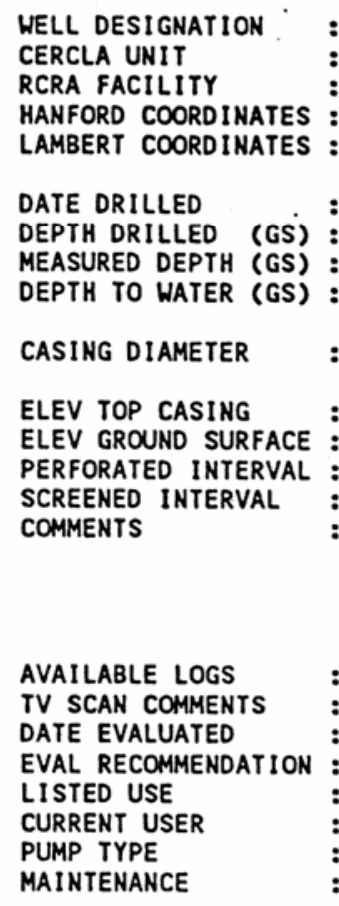


299-E25-93

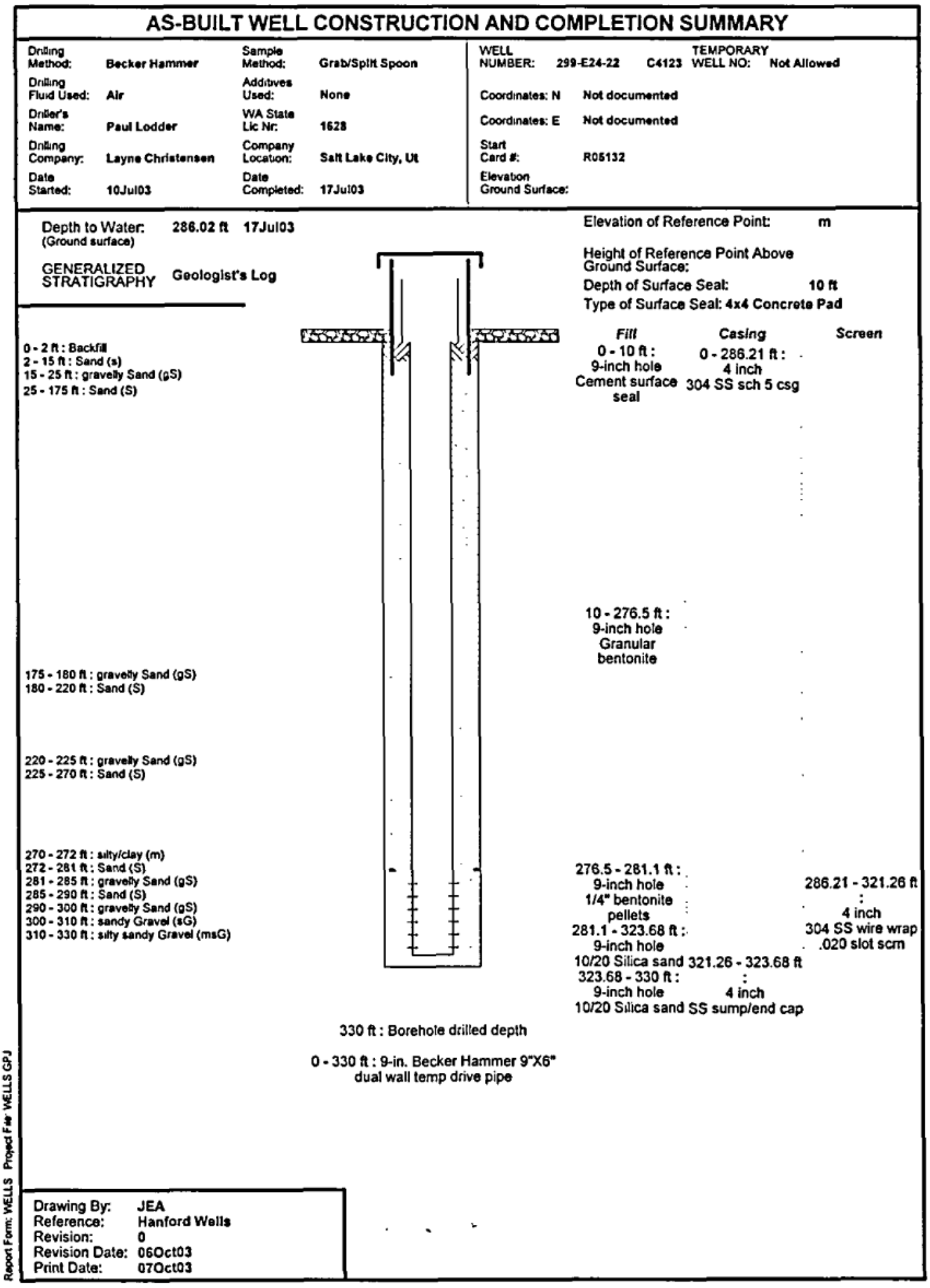




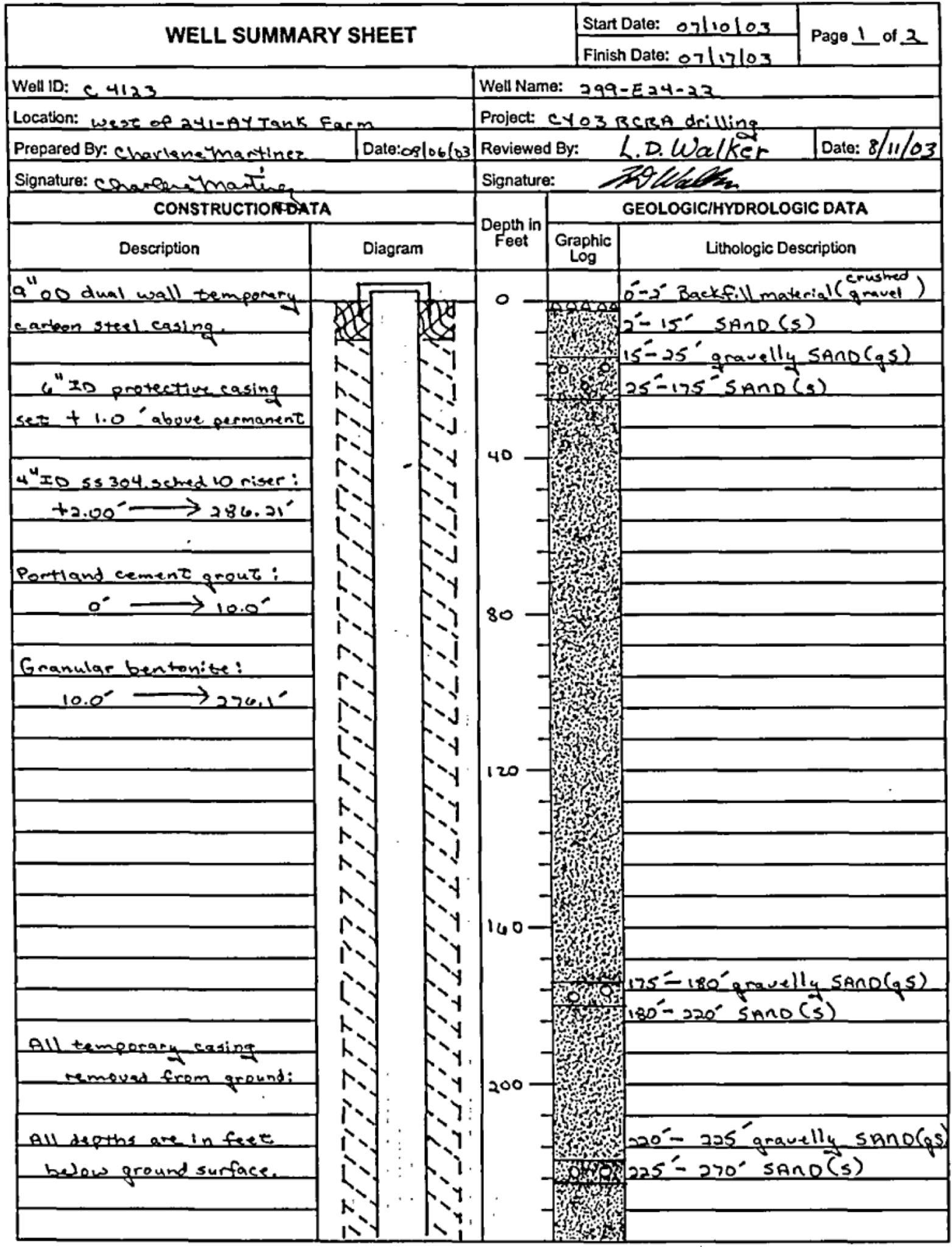




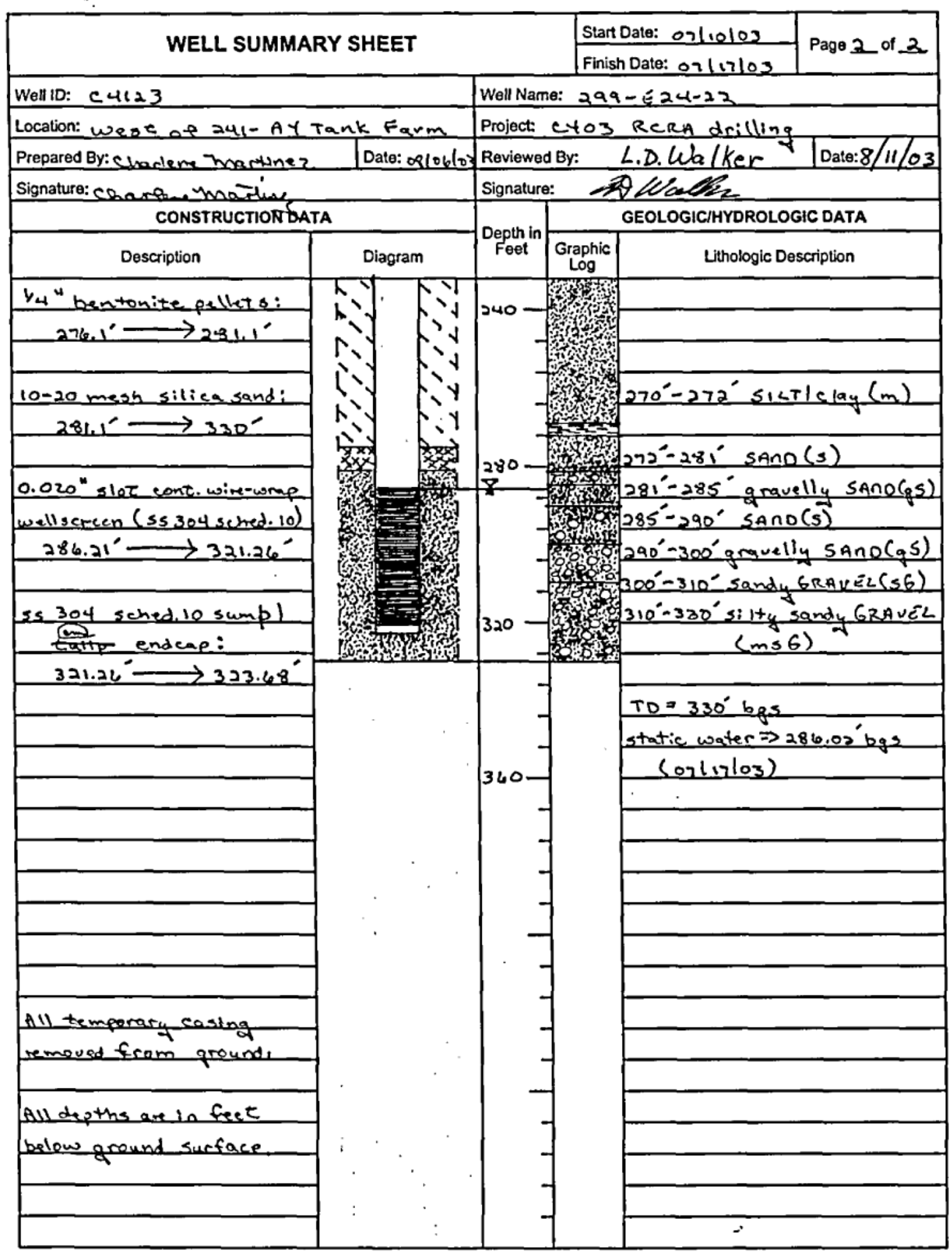


299-E25-93

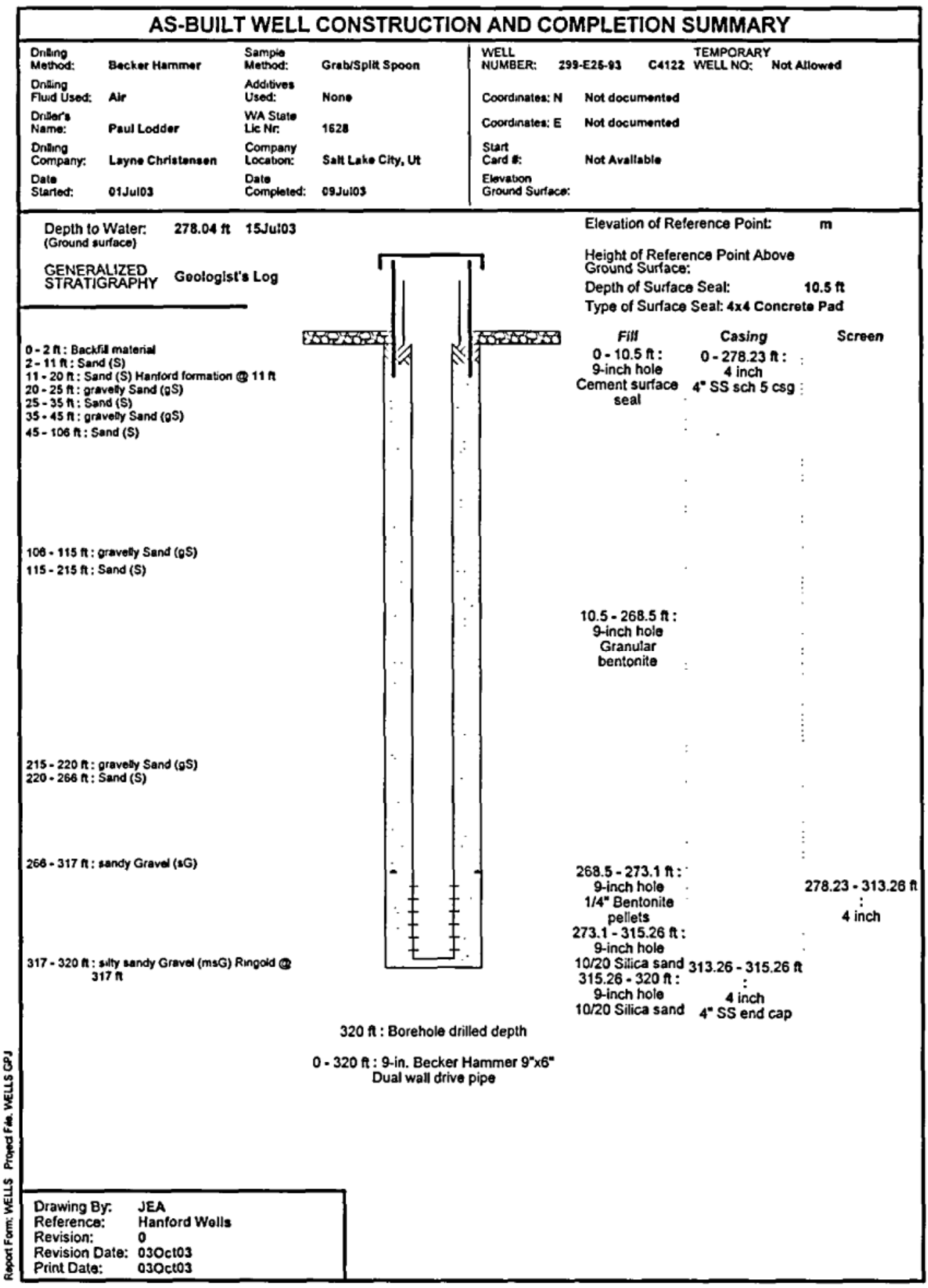




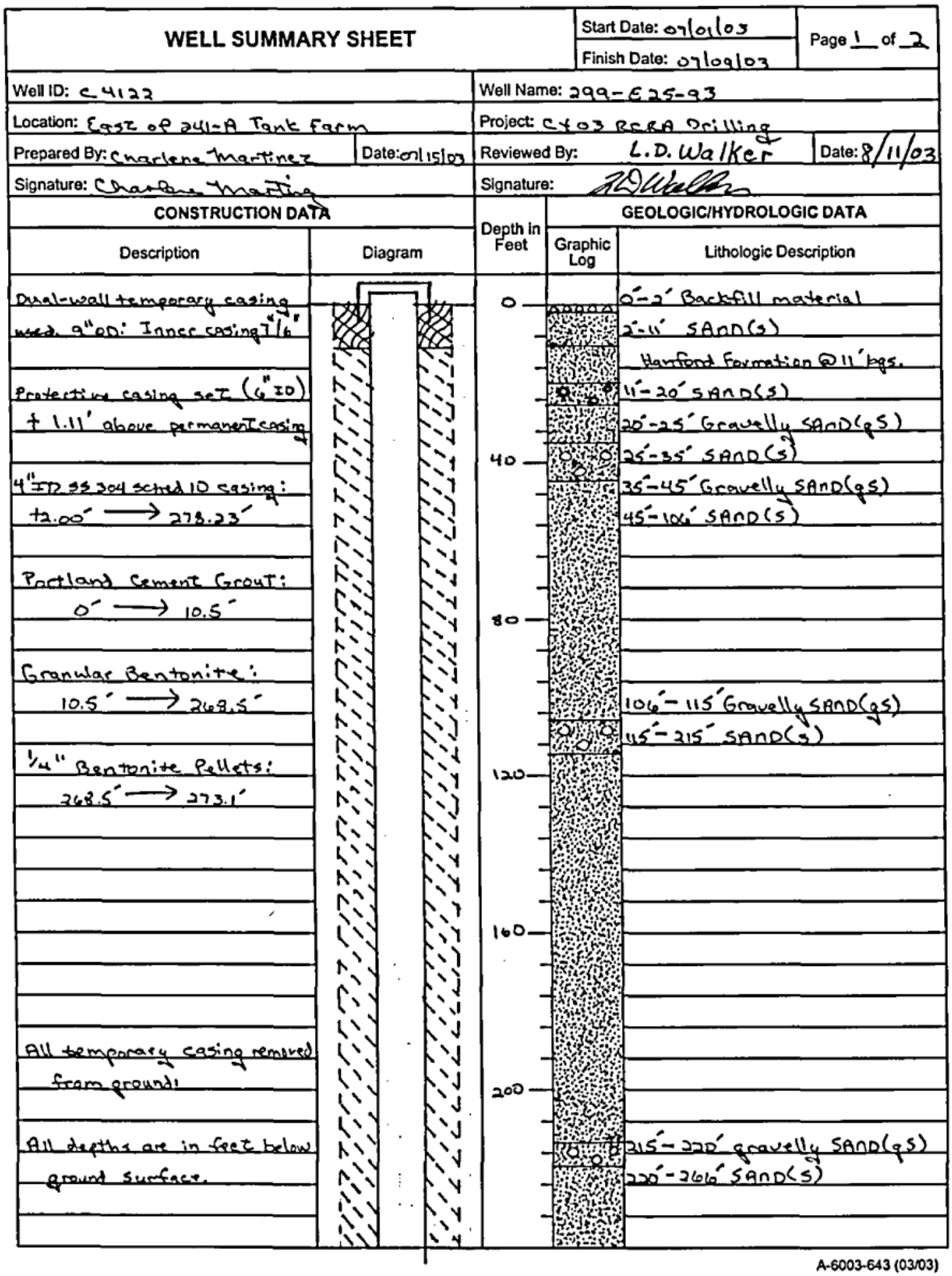




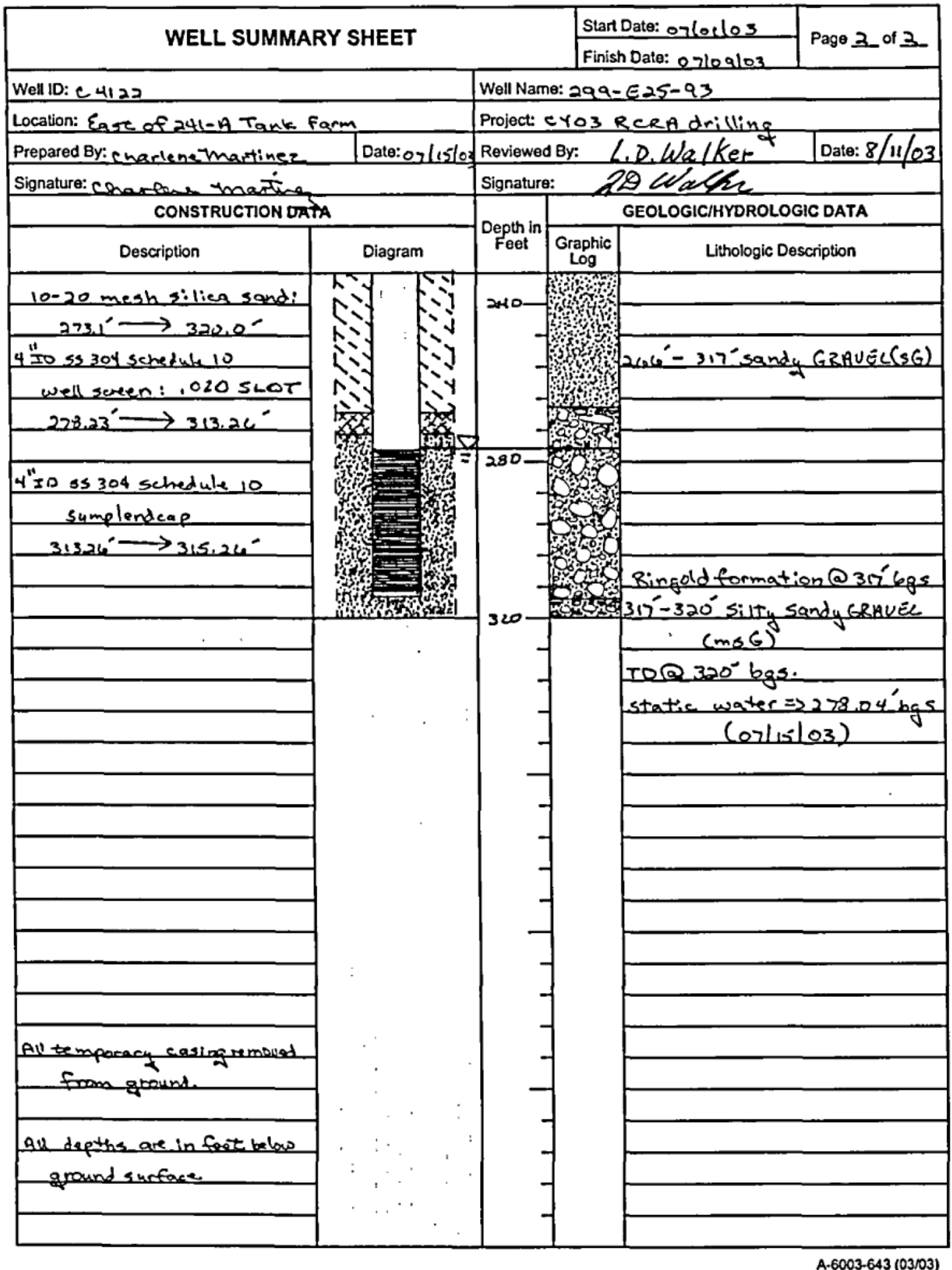




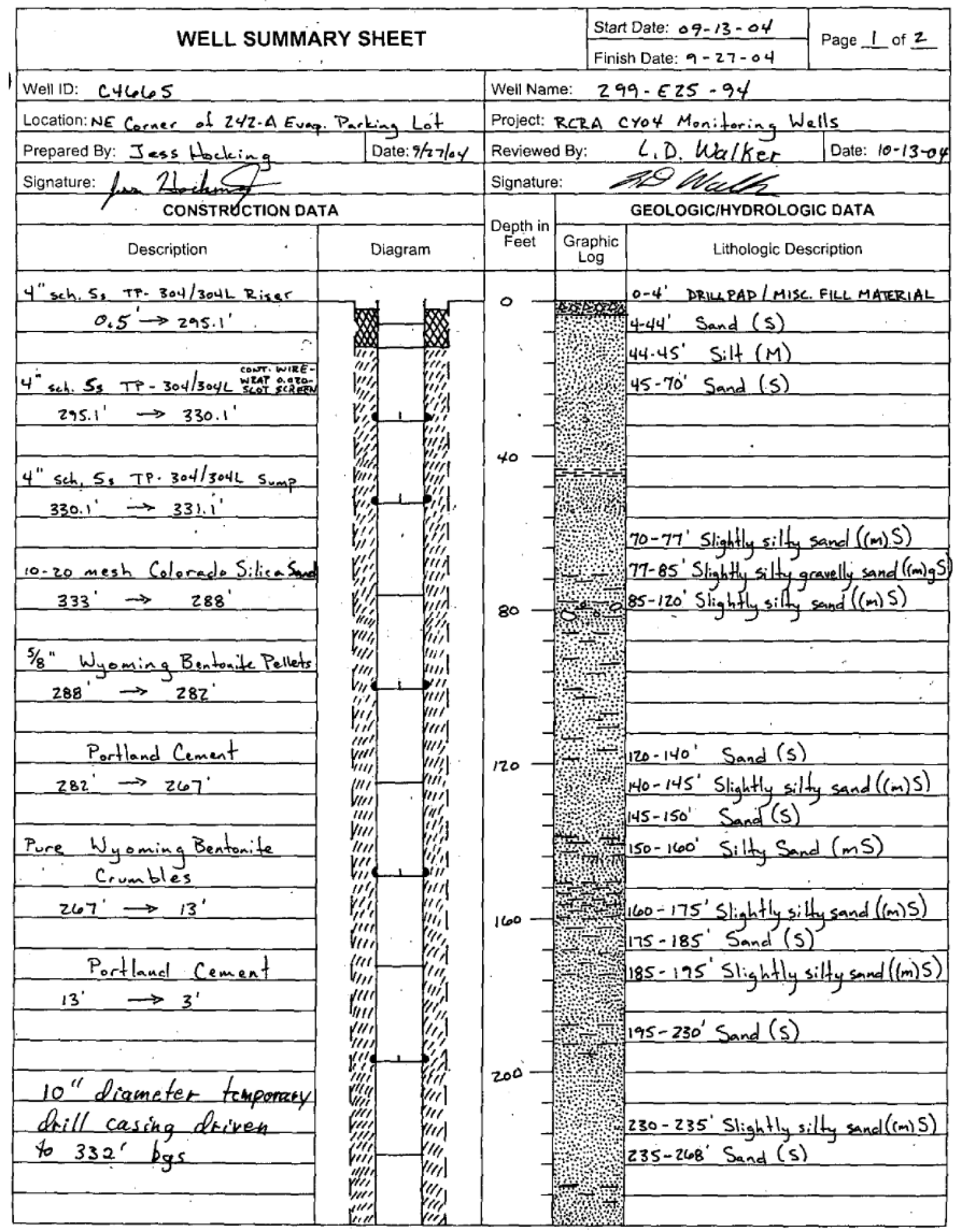




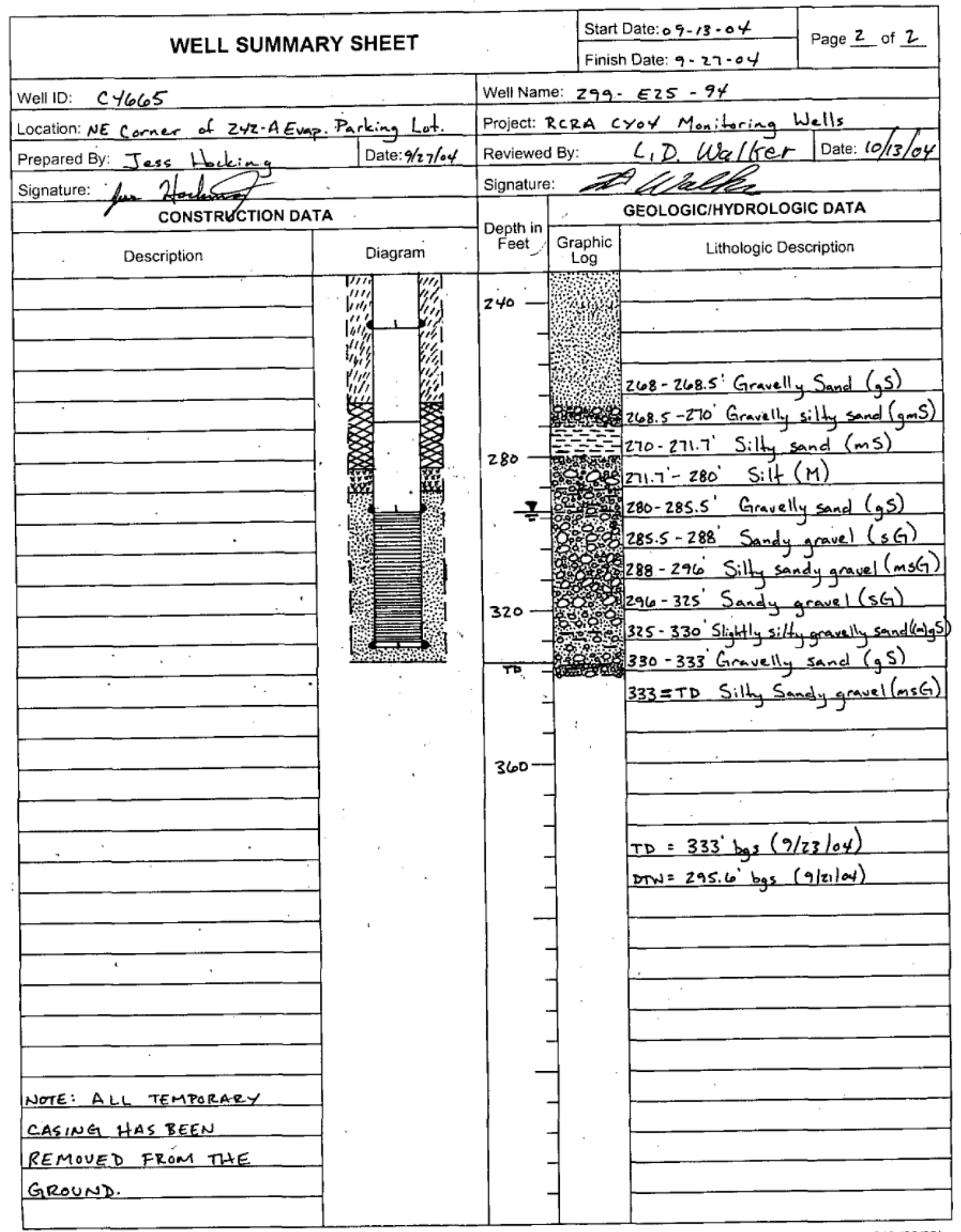




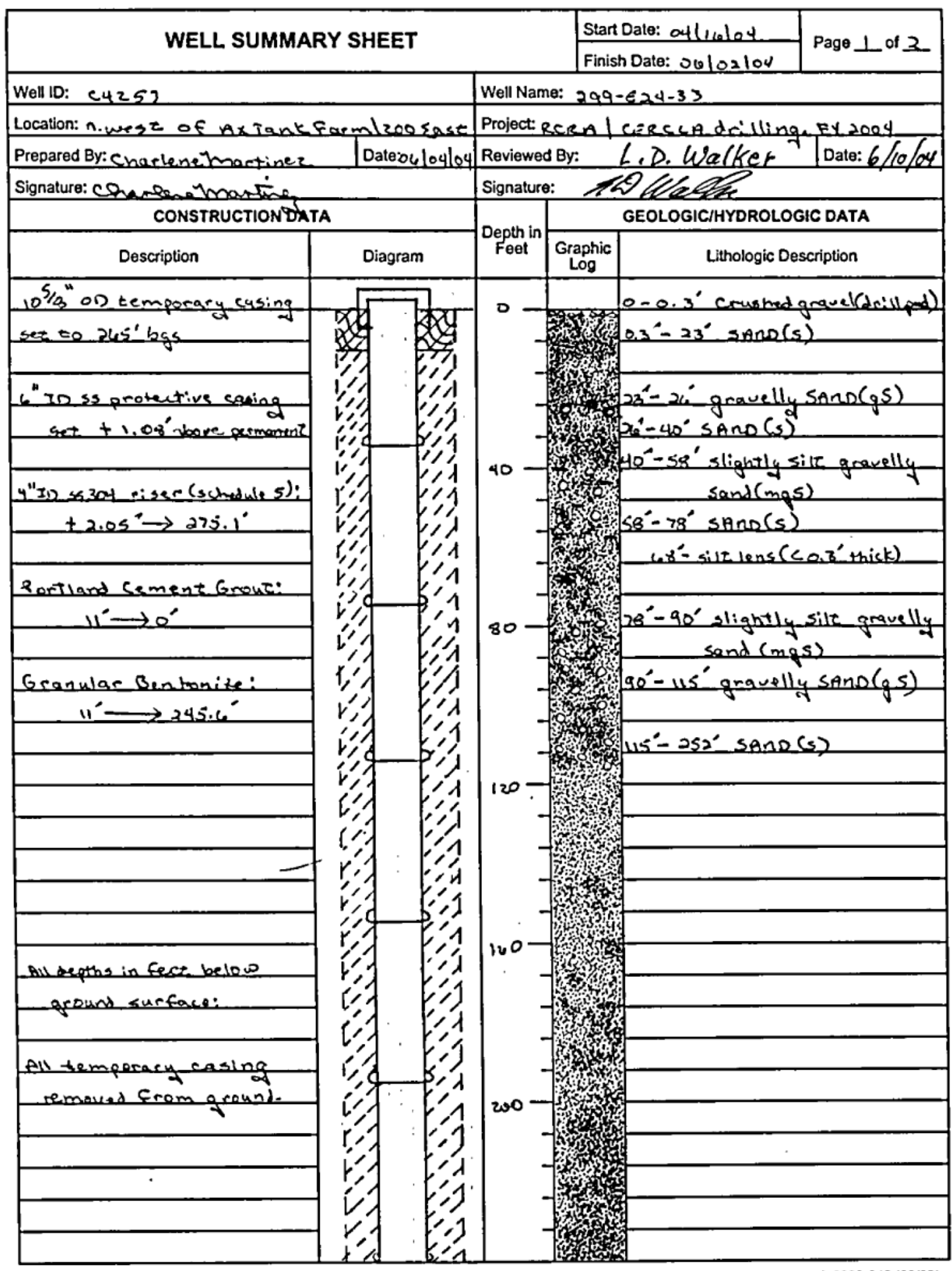




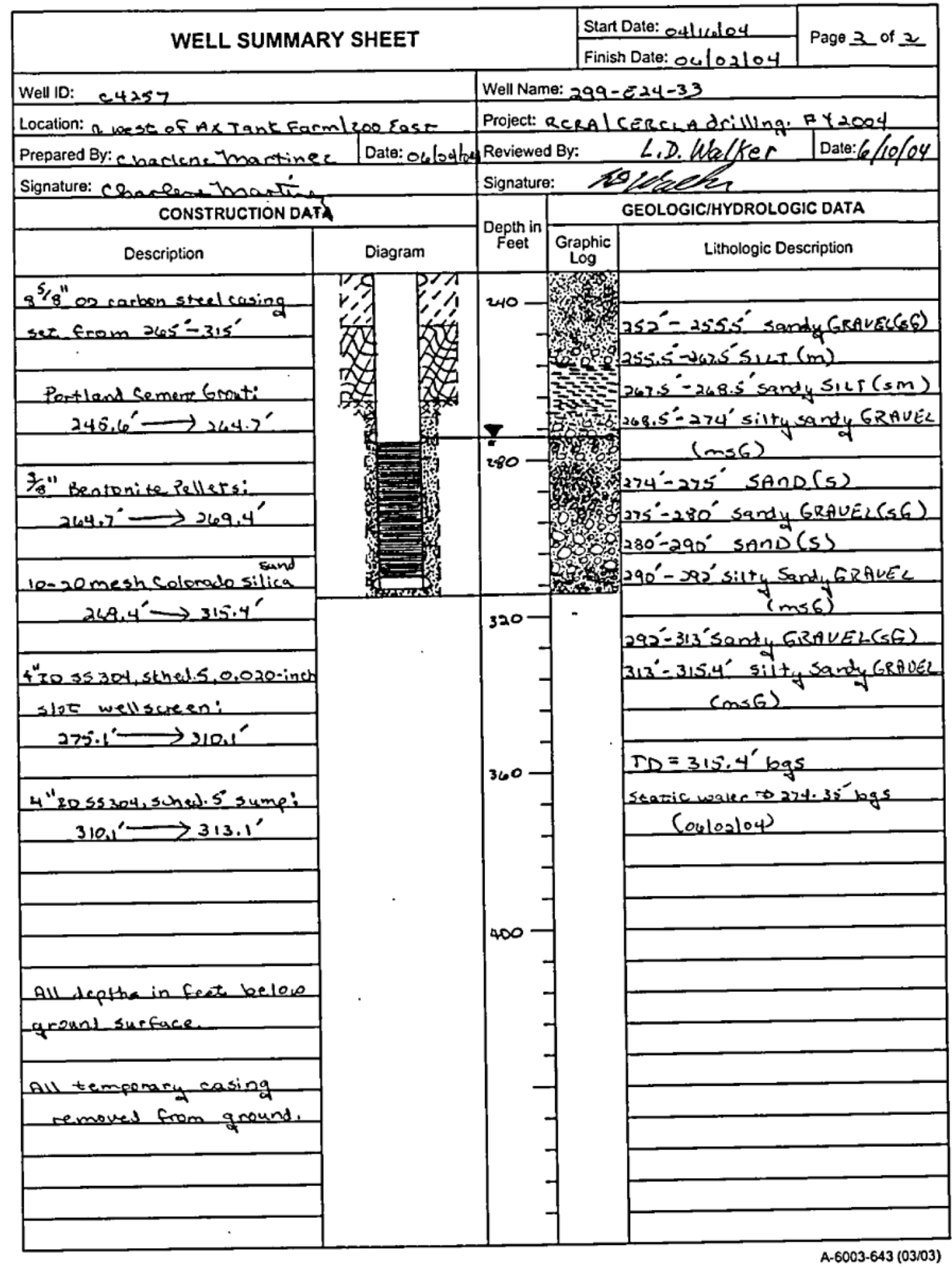




\section{Distribution}

No. of

Copies

\section{OFFSITE}

Confederated Tribes of the Umatilla

Indian Reservation

P.O. Box 638

Pendleton, OR 97801

ATTN: The Honorable W. Burke (CD)

T. Rapaske (CD)

R. Jim, Manager (CD)

Environmental Restoration/

Waste Management Program

Confederated Tribes and Bands of the

Yakama Indian Nation

P.O. Box 151

Toppenish, WA 98948

Nez Perce Tribe

P.O. Box 365

Lapwai, ID 83540

ATTN: D. Landeen (CD)

D. Powaukee (CD)

S. Van Verst (CD)

Washington State Department of Health

Division of Radiation Protection

P.O. Box 47827

Olympia, WA 98504

\section{ONSITE}

\section{U.S. Environmental Protection Agency}

C. E. Cameron (CD)

B1-46

D. A. Faulk (CD)

B1-46
No. of

Copies

Washington State Department of Ecology

J. Caggiano (CD/P) H0-57

D. Goswami (CD) H0-57

J. A. Hedges (CD) H0-57

Fluor Hanford, Inc.

J. V. Borghese (CD) E6-35

G. D. Cummins (CD) H8-12

B. H. Ford (CD) E6-35

M. I. Wood (CD) H8-44

CH2M Hill Hanford Group, Inc.

F. J. Anderson (CD) E6-35

D. A. Myers (CD) H6-03

2 DOE-Richland Operations Office

R. D. Hildebrand (CD) A6-38

R. W. Lober (CD) H6-60

K. M. Thompson (CD) A6-38

Public Reading Room (2P) H2-53

2 Pacific Northwest National Laboratory

C. J. Chou (P) K6-75

M. J. Hartman (CD) K6-96

J. W. Lindberg (CD) K6-96

S. P. Luttrell (CD) K6-96

S. M. Narbutovskih (P) K6-96

Hanford Technical Library (2CD) P8-55

$\mathrm{CD}=\mathrm{CD}-\mathrm{ROM}$

$\mathrm{P}=$ Paper 